\title{
Relações Econômicas Internacionais, Isomorfismo Institucional e Democracia na América Latina. Explicando as Convergências (Inesperadas?) entre Uruguai, Brasil e Honduras*
}

\author{
Dawisson Belém Lopes
}

( presente estudo parte da inquietação de seu autor diante dos resultados expressos pelo informe "La Democracia en América Latina - Hacia una Democracia de Ciudadanos y Ciudadanas", documento divulgado pelo Programa de las Naciones Unidas para el Desarrollo - PNUD (2004a). A repercussão dos resultados dessa pesquisa deu vazão a um grande número de interpretações sobre o estado de saúde da democracia na América Latina. O propósito do PNUD foi investigar um quadro aparentemente paradoxal: em face do insatisfatório desempenho econômico dos países latino-americanos ao longo dos anos 1990, associado a um quadro de intensas reformas do Estado (o que significou, em regra, uma concomitante retração deste vis-à-vis um avanço das estruturas de mercado), sob que circunstâncias se fez possível a relativa estabilização das práticas democráticas no subcontinente?

A própria elaboração da pergunta - central à pesquisa do PNUD - embute os valores em que assentam os estudiosos responsáveis pela condução dos trabalhos. Passemos em revista os supostos: em primeiro lu-

\footnotetext{
*Se detentor de algum mérito acadêmico, este artigo o deve, sobretudo, às indicações e comentários de Bruno Reis, Carlos Aurélio Pimenta de Faria, Fátima Anastasia, Leonardo Ramos e Renato Boschi - professores a quem devo gratidão. Agradeço também aos pareceristas anônimos de DADOS pelas ponderações feitas ao argumento do texto, de que esta versão final se beneficiou largamente. Registro ainda, para efeito de disclaimer, que são de exclusiva responsabilidade do autor as carências e os equívocos que o artigo certamente conserva.
}

DADOS - Revista de Ciências Sociais, Rio de Janeiro, Vol. 50, nº3, 2007, pp. 611 a 652. 


\section{Dawisson Belém Lopes}

gar, presume-se não apenas a compatibilidade, senão a relação benigna (e desejável) entre democracia e desenvolvimento econômico. Esta relação remete aos escritos originais de Seymour Lipset, publicados em meados dos anos 1950 (Paramio, 2002a:16). Contudo, nem sempre se acreditou possível a convivência harmônica entre estas categorias democracia e desenvolvimento. Merquior lembra que a economia clássica, teorizadora do mercado, era ideologicamente alheia - e até antipática - ao princípio democrático ${ }^{1}$. Coube aos economistas neoclássicos, já no avançado do século XIX, "celebrar as núpcias entre teoria econômica e visão democrática" (Merquior, 1982:134). Hoje, a relação positiva entre democracia e desenvolvimento é pedra de toque da maior parte dos trabalhos acadêmicos nesta seara. Tornou-se ponto de partida, e não mais hipótese - ainda que estejamos cercados de evidências empíricas mistas e inconcludentes a respeito (cf., principalmente, Przeworski et alii, 2000). Os informes do PNUD (2004a; 2004b; 2004c) incorporam a regra.

É importante, em segundo lugar, compreender o que se pretende por "estabilização das práticas democráticas" no contexto latino-americano. Aqui, a abordagem do PNUD é procedimentalista: importa, para os efeitos pretendidos pelo informe, saber se o país em exame conta com quatro elementos, quais sejam, (a) sufrágio universal; (b) eleições limpas; (c) eleições livres; e (d) acesso a cargos públicos via eleições. Uma vez presentes os quatro elementos arrolados, estará atestado o caráter eleitoralmente democrático de um regime (PNUD, 2004b).

A perplexidade suscitada pelos referidos informes do PNUD (2004a; 2004 b; 2004c) apresenta-se da seguinte maneira: se a democracia e o desenvolvimento devem preferencialmente caminhar juntos (proposição de Lipset), como, então, explicar a hipótese de a democracia nos países latino-americanos ter-se estabilizado - bem entendido: "democracia" nos termos descritos pelo PNUD - a despeito do insatisfatório desempenho econômico daqueles países ao longo das duas últimas décadas? Boschi (um dos pesquisadores que colaboraram para o debate conceitual do PNUD sobre a democracia latino-americana) adiciona dois pontos: "se o legado histórico da América Latina não favorece a democracia, o contexto tampouco o faz, tanto de um ponto de vista econômico quanto de uma perspectiva das características do sistema internacional, começando da conjuntura da Guerra Fria até chegar ao cenário atual, de predomínio da violência e do terrorismo internacional" (Boschi, 2004b:216, tradução do autor). 
A passagem desperta dúvida. Afinal, se parece evidente que a democracia (sob o prisma teórico do institucionalismo histórico) não deita raízes profundas em solo latino-americano, afigura-se pouco clara a conexão entre o contexto internacional vigente e a democracia que se configurou nestas paragens. A rigor, as relações internacionais contemporâneas ajudam ou interferem no arraigamento das práticas democráticas em um subcontinente - política e economicamente periférico - como o nosso?

Tradicionalmente, as relações interno/internacional e as implicações que estas relações guardam com os processos de democratização e desenvolvimento não têm merecido a devida ênfase da parte dos pesquisadores. Muitos são os que ignoram a dimensão internacional dos processos que se dão no bojo dos estados, entendendo não se tratar de variável (ou conjunto de variáveis) que mereça maior atenção (Naim, 1993; Przeworski, 1994). Outros tentam equiparar a pressão internacional a fatores domésticos, tais como a cultura política, a legitimidade e os interesses das elites (Varas apud Zovatto, 2002). Há ainda quem busque, por meio de abordagem cognitivista, entender os mecanismos psicológicos por detrás das tomadas de decisão dos governantes (Weyland, 1998; 2002). Uma terceira linha de teóricos, à qual sou simpático, busca assinalar a impossibilidade de se estabelecer qualquer relação causal a respeito dos processos de democratização e desenvolvimento na América Latina que não leve em conta a complexa teia de relações internacionais que conformam a inserção do subcontinente latino-americano no mundo (Ikenberry, 1990; Gilpin, 2004; Henisz, Zelner e Guillén, 2004; Pevehouse, 2002). Entender o "estar no mundo" da América Latina seria, pois, precondição para algum avanço na compreensão da problemática das relações entre democracia e desenvolvimento.

Mas a que "contexto internacional" se está a referir? Aludo ao contexto em que se deram as reformas institucionais do Estado latino-americano - ou seja, às décadas de 1980 e, sobretudo, 1990. Durante esse período, muito se passou: a gradual dissipação do clima de Guerra Fria e a ruína do "império" soviético trouxeram consigo a disseminação, em escala global, dos valores liberal-democráticos (Fukuyama, 1992; Ruggie, 1998); propagou-se uma espécie de receituário econômico de cunho ortodoxo, basilar às reformas do Estado, levando ao que alguns perceberam como o predomínio da economia sobre a política; a assertividade com que as relações econômicas internacionais modularam as 
reformas institucionais do Estado latino-americano fez-se notar pela pronta assimilação (e propagação) do rótulo "reformas neoliberais". Comum foi a percepção de que as reformas estruturais na América Latina se deviam ao encaminhamento das relações internacionais pósGuerra Fria. Para sobreviver em um mundo dito globalizado, seria necessário para o Estado reformar-se - e fazê-lo segundo ditames mercadológicos, emanados dos centros econômicos mundiais.

Quão acurada é essa percepção? Poder-se-á argüir, contrario sensu, que os governos nacionais adotam o curso das reformas institucionais orientadas para o mercado em virtude de fatores domésticos, tais como o desempenho incipiente de alguns setores da economia, as pressões de grupos de interesse, a deterioração do quadro fiscal ou a busca por avanços tecnológicos (Henisz, Zelner e Guillén, 2004). Em que pesem tais alegações, apresento aqui a hipótese de que, não fossem as pressões internacionais pelas reformas neoliberais, nenhum desses fatores internos seria decisivo a ponto de fazer mudar toda a formatação institucional do Estado latino-americano.

Portanto, eis a primeira hipótese a ser discutida neste artigo: a de que as reformas orientadas para o mercado na América Latina estão diretamente relacionadas à incidência das forças econômicas internacionais. Imputar relações de causalidade ao movimento reformista dos anos 1980 e 1990 na América Latina requer, antes de tudo, compreender a dinâmica das relações econômicas internacionais.

Caso as forças econômicas internacionais sejam realmente as maiores responsáveis pela remodelagem institucional do Estado latino-americano, quão autônomo estará o seu povo para determinar o seu rumo? $\mathrm{Ou}$, noutros termos: se os países latino-americanos estiverem, de fato, submetidos, de forma irresistível (como se costuma alegar), a uma lógica dos mercados internacionais (o que aqui chamo de relações econômicas internacionais), quão legítima será a democracia - ou seja, o governo do povo - exercida sob tais condições? Ainda que se reconheçam os avanços institucionais, em que extensão foi possível concretizar o ideal da democracia na América Latina de hoje? Para mais, qual o grau de adequação entre a conduta democrática (preconizada pelo PNUD) e o ideal democrático no subcontinente latino-americano? Por mais que sejamos democratas (praticantes da democracia eleitoral, nos termos do PNUD), poderíamos nos considerar politicamente democráticos? 
Se eu estiver correto a respeito da crença no papel decisivo que as relações econômicas internacionais exercem sobre o Estado latino-americano (o que estaria substanciado na adoção das reformas orientadas para o mercado), a concepção que se defenderá adiante é a da inviabilidade de se colocar em prática, na América Latina, um arranjo institucional que se aproxime de uma noção mais substantiva de democracia. $\mathrm{Ou}$, posto de outra forma: acredito ser difícil a conjugação de uma lógica pura de mercado com uma lógica puramente democrática. Avanços na real democratização de uma sociedade implicam certos retrocessos da mercantilização dessa mesma sociedade, e vice-versa (Hanson, 1999). Para o propósito do artigo, considerarei, portanto, a relação de trade-off existente entre a democracia e o mercado - como, de resto, o faz o próprio PNUD (2004a).

Segue, assim, minha segunda hipótese: a de que a democracia possível na América Latina é formalista e pouco substanciosa porque está calcada em procedimentos que não impedem os agentes racionais - orientados pela lógica das relações econômicas internacionais - de atingir os seus objetivos, mesmo que à custa dos ideais democráticos. A hipótese envolve a suposição adicional de que os cidadãos latino-americanos não têm consciência do sentido da democracia, sendo incapazes de aquilatar o poder de alocação dos recursos públicos que eles, cidadãos, detêm em mãos. Hipótese a investigar.

Rearranjando fatores, tentarei decifrar a lógica que estrutura a relação triangular entre (a) as forças econômicas internacionais; (b) as reformas institucionais do Estado; e (c) a democracia na América Latina. O processo dar-se-á em duas etapas: (1) o estudo das relações entre reformas neoliberais na América Latina e forças econômicas internacionais; e (2) a apreciação dos nexos entre as relações econômicas internacionais e a democracia na América Latina.

Para tanto, parece indispensável o suporte factual. A relação triangular, anteriormente sugerida, será analisada por meio do acompanhamento da evolução das reformas neoliberais e de seus desdobramentos em três países da América Latina: Uruguai, Brasil e Honduras. Essa seleção de países não é fortuita. Seguem alguns critérios formais, tais como a disponibilidade de dados (confiáveis) e a presença [dos três países] no conjunto dos 19 países pesquisados para a elaboração do informe do PNUD (2004a); além de critérios arbitrários, estabelecidos por mim, notadamente a constatação de uma convergência nas trajetórias 
de "reformas do Estado" nesses países, a despeito das diferenças históricas, geográficas, étnicas, demográficas, sociais e econômicas que os três, Uruguai, Brasil e Honduras, ostentam entre si. Paralelamente, serão também analisados os dados agregados referentes à América Latina.

Tabela 1

Indicadores Socioeconômicos

\begin{tabular}{l|c|c|c|c|c}
\hline País/Região & $\begin{array}{c}\text { Desenvolvi- } \\
\text { mento Hu- } \\
\text { mano (IDH) }\end{array}$ & $\begin{array}{c}\text { Alfabetização } \\
\text { (\% População } \\
\text { Adulta) }\end{array}$ & $\begin{array}{c}\text { Expectativa } \\
\text { de Vida (em } \\
\text { Anos) }\end{array}$ & $\begin{array}{c}\text { Renda Bruta } \\
\text { per Capita } \\
\text { (PPP US\$) }\end{array}$ & $\begin{array}{c}\text { Posição no } \\
\text { Mundo } \\
\text { (IDH) }\end{array}$ \\
\hline Uruguai & 0,833 & 97,7 & 75,2 & 7.830 & 46 \\
Brasil & 0,775 & 86,5 & 68 & 7.770 & 72 \\
Honduras & 0,672 & 80 & 68,8 & 2.600 & 115 \\
América Latina & 0,777 & 88,6 & 70,5 & 7.223 & $\sim 70$ \\
Países da OCDE* & 0,911 & - & 77,1 & 24.904 & $\sim 20$ \\
\hline
\end{tabular}

Fonte: PNUD (2004d).

* Organização para a Cooperação e Desenvolvimento Econômico.

\section{O PESO DAS RELAÇÕES INTERNACIONAIS}

Pôr em apreço a primeira hipótese requer o conhecimento da evolução das reformas econômicas na América Latina. A Tabela 2, produzida a partir de dados disponibilizados pela Comisión Económica para América Latina - CEPAL (1999) ${ }^{2}$ e PNUD (2004b) ${ }^{3}$, é um bom ponto de partida. Em primeiro lugar, chama a atenção o fato de que os dois conjuntos de índices, elaborados por CEPAL e PNUD, parecem apontar para um mesmo horizonte - malgrado tratar-se de duas entidades com orientações teóricas e abordagens metodológicas distintas. Segundo, fica patente a curva ascendente no tocante às reformas para o mercado na América Latina, ao longo dos últimos 30 anos. Mas há sensíveis diferenças entre os países em exame, sobretudo no aspecto do timing: o Uruguai atinge um limiar de país liberalizado (índice $=0,8$ ) já no início dos anos 1980, ao passo que Brasil e Honduras só o atingiriam por volta de 1995. O gradualismo do caso uruguaio, contrastado ao ritmo acelerado das reformas no Brasil e em Honduras, fica ilustrado nos dados relativos às duas últimas décadas: enquanto o primeiro evolui lentamente de um indicador 0,76 (1980) para 0,83 (2000), os dois últimos dão verdadeiros saltos (de 0,49 para 0,81 , no Brasil; de 0,65 para 0,85 , em Honduras). O passo decisivo no processo de reformas uruguaio deu-se 
ainda nos anos 1970, quando o país avançou de um status de economia fechada (0,39 em 1970) para o de economia aberta (0,76 em 1980). Terceiro, refutando o senso comum, a evolução dos índices sugere que os anos 1990 não constituíram exatamente o período mais denso em termos de reformas do Estado na América Latina (ou, como preferiram alguns, a "década neoliberal"). A rigor, a seqüência dos dados aponta para a maior concentração de reformas nos anos compreendidos entre 1985 e 1995 (ver Figura 1). Portanto, se houve uma "década neoliberal" na América Latina, ela inclui a segunda metade dos 1980 e a primeira metade dos 1990.

Tabela 2

Índice de Evolução Global das Reformas Econômicas Orientadas para o Mercado

\begin{tabular}{l|c|c|c|c|c|c|c|c|c|c|c}
\hline \multirow{2}{*}{ País/Região } & $\mathbf{1 9 7 0}$ & $\mathbf{1 9 7 5}$ & $\mathbf{1 9 8 0}$ & \multicolumn{2}{c|}{1985} & \multicolumn{2}{c|}{1990} & \multicolumn{2}{c|}{1995} & $\mathbf{2 0 0 0}$ \\
\cline { 2 - 11 } & \multicolumn{3}{|c}{ CEPAL } & CEPAL & PNUD & CEPAL & PNUD & CEPAL & PNUD & PNUD \\
\hline Uruguai & 0,39 & 0,5 & 0,76 & 0,82 & 0,83 & 0,84 & 0,79 & 0,89 & 0,82 & 0,83 \\
Brasil & 0,54 & 0,5 & 0,49 & 0,49 & 0,48 & 0,72 & 0,69 & 0,81 & 0,79 & 0,81 \\
Honduras & 0,6 & 0,63 & 0,65 & 0,63 & 0,62 & 0,62 & 0,62 & 0,78 & 0,78 & 0,85 \\
América Latina* & 0,47 & 0,49 & 0,55 & 0,54 & 0,54 & 0,68 & 0,68 & 0,82 & 0,80 & 0,83 \\
\hline
\end{tabular}

Fontes: CEPAL (1999) e PNUD (2004b).

* Os índices da CEPAL (1999) referem-se a um levantamento de dados acerca de 17 países latino-americanos: Argentina, Bolívia, Brasil, Chile, Colômbia, Costa Rica, El Salvador, Equador, Guatemala, Honduras, Jamaica, México, Paraguai, Peru, República Dominicana, Uruguai e Venezuela. Os índices do PNUD (2004b) referem-se a 18 países. À listagem de países da CEPAL, subtrai-se a Jamaica e adicionam-se a Nicarágua e o Panamá.

Figura 1

Gráfico de Evolução Global das Reformas Econômicas Orientadas para o Mercado

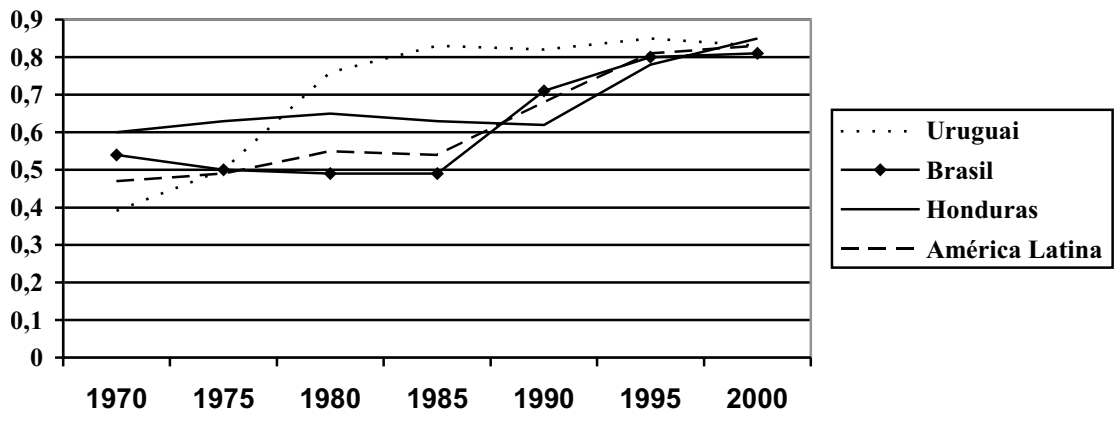

Fontes: CEPAL (1999) e PNUD (2004b). 
Internacionalmente, o cenário foi bastante movimentado durante o período de culminância das reformas (1985-1995). Compreendeu, dentre outros, os primeiros anos da redemocratização na América Latina e no Leste Europeu, a queda do muro de Berlim (1989), o fim da União Soviética (1991), o fim da Guerra Fria e a proliferação do ideário liberal-democrático pelo mundo (Fukuyama, 1992; Ruggie, 1998). Não é por acaso que, na primeira metade dos anos 1990, se tenha dado o lançamento de vários experimentos de livre-comércio regional (AsiaPacific Economic Cooperation - APEC (1989), Área de Livre Comério das Américas - ALCA (1990), Mercado Comum do Sul - Mercosul (1991), União Européia (1992), North America Free Trade Agreement NAFTA (1994)), bem como a criação da Organização Mundial do Comércio - OMC (1994), além do sem-número de acordos bilaterais de livre-comércio e cooperação que se celebraram na América Latina e no mundo. As relações econômicas internacionais encontravam-se em intensa atividade.

Os dados apresentados em PNUD (2004b) bem ilustram o modelo de inserção econômica internacional adotado pela América Latina. Percebe-se a evolução positiva da participação das exportações no Produto Interno Bruto - PIB no Uruguai, Brasil e Honduras, assim como em toda a América Latina, entre 1980-2000. A única guinada significativa ocorre no Brasil, onde a relação exportações/PIB mais que duplica no curso dos últimos 20 anos. Uruguai e Honduras, dois países de economias tradicionalmente mais extrovertidas, também experimentam ligeiros acréscimos no coeficiente exportações/PIB durante os anos de reformas do Estado. A Tabela 3 mostra a evolução do investimento externo líquido - IEL, no curso da década de 1990, em nosso subcontinente. Nitidamente, a parábola segue uma trajetória ascendente a partir de 1992, atingindo o ponto mais alto da curva entre 1998-2001, e, então, declina rapidamente, nos três países. O período de 1998-2001 corresponde ao ponto alto das privatizações das empresas estatais na América Latina. Ao que se pôde perceber, com o esgotamento dos ativos do Estado latino-americano e a ocorrência de crises financeiras (Brasil, em 1999; Argentina, em 2001), o ânimo do investidor estrangeiro para remeter divisas diminuiu sensivelmente.

Há também o aprofundamento da dependência do financiamento externo para o investimento interno bruto no Estado latino-americano. No ínterim 1990-2001, esse percentual subiu de 6,7 para 28,2 - na média dos países da América Latina. Dá-se a transição de um modelo de "tu- 
Tabela 3

Investimento Estrangeiro Líquido

(em Milhões de US\$)

\begin{tabular}{l|c|c|c|c|c|c|c|c|c|c|c}
\hline País/Região & $\mathbf{1 9 9 2}$ & $\mathbf{1 9 9 3}$ & $\mathbf{1 9 9 4}$ & $\mathbf{1 9 9 5}$ & $\mathbf{1 9 9 6}$ & $\mathbf{1 9 9 7}$ & $\mathbf{1 9 9 8}$ & $\mathbf{1 9 9 9}$ & $\mathbf{2 0 0 0}$ & $\mathbf{2 0 0 1}$ & $\mathbf{2 0 0 2}$ \\
\hline Uruguai & 0 & 102 & 155 & 157 & 137 & 113 & 155 & 229 & 280 & 319 & 168 \\
Brasil & 1.924 & 801 & 2.035 & 3.475 & 11.666 & 17.877 & 26.002 & 26.888 & 30.497 & 24.894 & 13.402 \\
Honduras & 48 & 52 & 42 & 69 & 90 & 128 & 99 & 237 & 282 & 195 & 179 \\
América Latina & 12.508 & 10.386 & 24.236 & 25.300 & 40.028 & 55.873 & 60.865 & 77.284 & 64.801 & 68.078 & 38.966 \\
\hline
\end{tabular}

Fonte: PNUD (2004b).

tela capitalista", comum aos anos de Guerra Fria, para a competitiva economia mundializada da década de 1990 . O caso de Honduras afigura-se exemplar: em 1980-1985, cerca de 47\% de seu investimento interno era patrocinado por fontes externas; no ano de 1995, esse número havia despencado para 14\% (PNUD, 2004b). Ocorre que, por ocasião da revolução sandinista, na Nicarágua, os Estados Unidos posicionaram tropas em território hondurenho, e ali se mantiveram durante os anos 1980, fazendo-se acompanhar por investimentos infra-estruturais no país. A retirada das tropas e a perda do interesse estratégico dos Estados Unidos em Honduras, com o fim da Guerra Fria, fizeram retroceder dramaticamente as cifras de ajuda externa ao governo hondurenho, levando à conseqüente deterioração de um quadro (já incipiente) de investimentos internos. A década de 1990 inaugura a era do "cada um por si" nas relações econômicas internacionais.

A combinação de dados fornecida pelas Tabelas 4, 5 e 6 joga luz sobre a natureza assimétrica das relações entre as forças da economia internacional e as reformas institucionais do Estado na América Latina. Na Tabela 4, percebemos como os três países, Uruguai, Brasil e Honduras, passaram por choques deflacionários na segunda metade dos anos 1990, vindo atingir taxas anuais de inflação de apenas um dígito no início dos anos 2000 (o repique inflacionário uruguaio, no ano de 2002, deveu-se, em larga medida, à crise argentina desencadeada no ano anterior). O paralelismo das mudanças de orientação de política econômica não é fortuito: em toda a América Latina, os preços passaram por uma estabilização assemelhada (não é demais lembrar que, no Brasil, tal controle inflacionário se deu a despeito de uma política fiscal pouco austera - pelo menos, até meados de 1999). Metas de inflação passaram a ser perseguidas pelos bancos centrais nacionais, com a aura de um verdadeiro "imperativo categórico". Cabe mencionar: a contenção da inflação é condicionalidade imposta pelos receituários econômicos 


\section{Dawisson Belém Lopes}

dos bancos multilaterais - os financiadores emergenciais das crises de liquidez na América Latina. A revoada rumo à estabilização dos preços é mais um considerável indício da submissão do Estado latino-americano aos parâmetros e fórmulas praticados nas relações econômicas internacionais. A esse propósito, a Tabela 5, de forma distinta, também sugere relações assimétricas entre economia internacional e Estado latino-americano: ao acompanhar a evolução dos dispêndios com a dívida externa, nos anos 1990, no Uruguai, Brasil e Honduras, constata-se um substancial aumento do montante revertido para as mãos dos credores internacionais (implicando, em decorrência, cortes de verbas que seriam destinadas a fins considerados socialmente mais legítimos, aos olhos da população). Em outras palavras: com as reformas estruturais do Estado latino-americano, aprofundou-se a dívida externa dos países, sem haver, no entanto, a esperada contrapartida social. No caso brasileiro, os pagamentos executados com a dívida externa chegaram a dobrar, em valores absolutos, no espaço de 10 anos (1990-2000). Na média do subcontinente latino-americano, a história não foi muito diferente: partindo-se de um montante de US\$ 435 bilhões, para o ano de 1990, chegou-se a desembolsar, com a dívida externa, cerca de US\$ 750 bilhões, no ano de 2001 - um incremento da ordem de $70 \%$ nas despesas. A Tabela 6 exemplifica o que o sociólogo alemão Ulrich Beck chamou de a "brasilianização" do mundo: o agravamento de uma situação de extrema concentração da renda nos países da OCDE - os países mais ricos do mundo - durante os 20 anos de reformas estruturais na América Latina (1980-2000). Nos anos 1980, enquanto a América Latina aumenta o seu PIB em 1,1\% a. a., os países da OCDE incrementam o seu produto interno à ordem de 3,0 \% a. a. - quase o triplo do crescimento econômico médio latino-americano.

A deterioração das relações trabalhistas também é percebida. A escalada do desemprego urbano na América Latina acentua-se na década de 1990, atingindo patamares recordes no início deste milênio. O problema do desemprego, apesar de não adstrito à região da América Latina, ganha contorno de dramaticidade em face da fraqueza da rede de proteção social aqui disponibilizada. Em Honduras, onde cerca de $80 \%$ da população total vive em condições de pobreza e miséria, a situação de desamparo é "preocupante" (PNUD, 2002). No Uruguai, que viu os seus índices de desemprego urbano duplicarem no intervalo de uma década, alega-se até a "perda de capital cívico" (idem, 2001). No Brasil e por todo o subcontinente, a questão do emprego ocupa o topo da lista de prioridades políticas para governados e governantes (idem, 2004b). 
Relações Econômicas Internacionais, Isomorfismo Institucional...
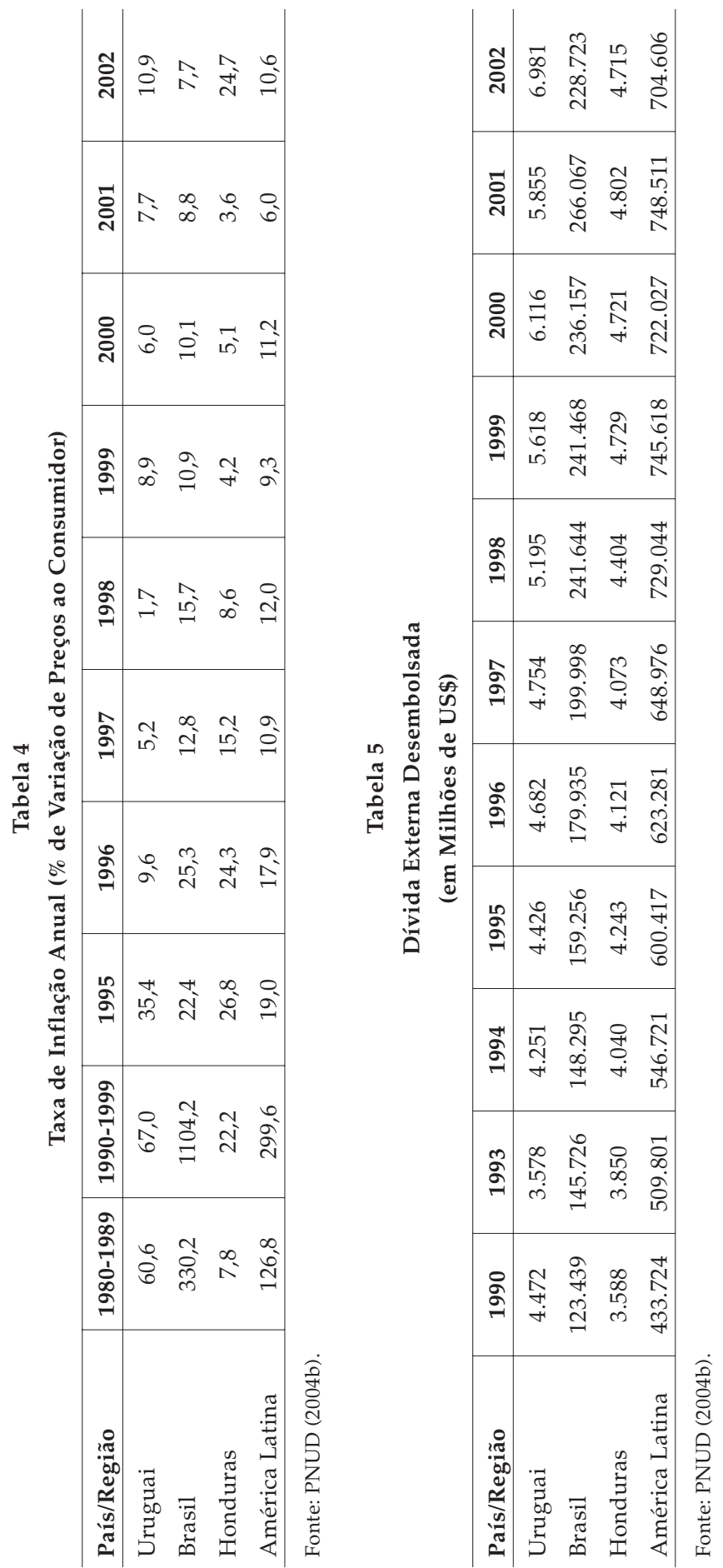
Tabela 6

Média Anual de Crescimento do Produto Interno Bruto

(\%)

\begin{tabular}{l|c|c|c}
\hline País/Região & $\begin{array}{c}\mathbf{1 9 8 0 - 1 9 9 0} \\
\text { (A) }\end{array}$ & $\begin{array}{c}\mathbf{1 9 9 0 - 2 0 0 0} \\
\text { (B) }\end{array}$ & (A)+(B)/2 \\
\hline Uruguai & 3,0 & 0,4 & 1,7 \\
Brasil & 1,6 & 2,6 & 2,1 \\
Honduras & 2,3 & 3,2 & 2,7 \\
América Latina & 1,1 & 3,2 & 2,2 \\
Países da OCDE & 3,0 & 2,3 & 2,6 \\
\hline
\end{tabular}

Fontes: PNUD (2004b) e OECD (2000).

A informalidade do trabalho, efeito colateral da degradação das relações trabalhistas, chega aos $45 \%$ da massa economicamente ativa na América Latina - ou seja: a economia do Estado latino-americano parece ter-se desmembrado em "oficial" e "paralela". Quase 80\% dos que têm emprego sentem-se "preocupados" ou "muito preocupados" com a manutenção deste. Com a globalização das estruturas produtivas e a necessidade dos ganhos de competitividade das economias nacionais, muitos dos ajustes têm-se dado pela via do chamado downsizing, ou seja, as demissões em massa e/ou reduções de jornadas e salários. A rigor, os dados ainda apontam que, durante os 20 anos em que se concentraram as reformas (1980-2000), se elevou a porcentagem de pobres $(40,5 \%$, em $1980 ; 43,8 \%$, em 1999) e se manteve a de indigentes (cerca de 18,5\%) na América Latina. Além disso, cresceu a população absoluta de pobres e de indigentes, no campo e na cidade. Se, em 1980, havia 136 milhões de pobres no subcontinente latino-americano, em 1999, eles passavam de 211 milhões. Durante o mesmo período, o número absoluto de pobres urbanos cresceu mais de $100 \%$ na América Latina (idem, 2004b).

Apesar das melhorias na distribuição da riqueza neste subcontinente, ao longo dos últimos anos, a desigualdade social continua elevada, com a maioria dos países a ostentar índices de Gini superiores a 0,5-a média dos países latino-americanos é de 0,544 (em 1999). O Uruguai tem sido o melhor exemplo de distribuição de renda (índice de aproximadamente 0,4) para o Brasil. Por sua vez, os índices de desigualdade socioeconômica do Brasil superam-se negativamente, aferição após aferição: no fim da década de 1990, os $10 \%$ mais ricos da população tiveram o seu quinhão da riqueza nacional acrescido em 9,3\%. Os 10\% 
mais ricos passaram a deter, em 1999, mais de 41 vezes a riqueza dos $10 \%$ mais pobres da população. Em um país considerado "socialmente justo", esse quociente não costuma ultrapassar o número de 10 vezes (no Uruguai, essa proporção é de 7,5 vezes). Honduras - país de pobreza reinante - tem evoluído positivamente nesse quesito em anos recentes, apesar de os seus $10 \%$ mais opulentos ainda concentrarem cerca de 22,5 vezes a riqueza dos $10 \%$ mais miseráveis.

\section{AS RAÍZES DO ISOMORFISMO INSTITUCIONAL}

Por que as relações econômicas internacionais têm presidido o ritmo e a natureza das reformas estruturais do Estado latino-americano? Ou, antes: por que países tão diferentes entre si - Uruguai, Brasil e Honduras - convergiram para um mesmo telos institucional, no tocante a suas reformas estruturais? ${ }^{4}$

Muitas opiniões há a respeito. Entre os que reputam à dinâmica doméstica dos estados as razões preponderantes para as reformas, Naim (1993) entende que a crise por que passou o Estado na América Latina foi severa a ponto de não deixar aos líderes políticos nacionais outra escolha além da adoção das reformas neoliberais - ainda que elas também trouxessem consigo os seus riscos (Weyland, 1998). Para Przeworski (1994), os políticos teriam optado pelos ajustes estabilizadores da economia como estratégia eleitoral, a fim de se manterem em seus cargos. Conaghan e Malloy (1994) atribuem à competição doméstica entre os capitalistas o desenvolvimento das reformas neoliberais. Sachs (1989) fala em uma "estratégia de choque" implementada pelos governos latino-americanos - as reformas neoliberais - como meio mais eficiente de se retomar o crescimento econômico. Veltmeyer, Petras e Vieux (1997) concebem as reformas como o movimento dirigido pelo Estado para defender os interesses da classe capitalista.

Entre os que reconhecem na cena internacional a principal força motriz para as mudanças estruturais do Estado latino-americano, as opiniões também divergem. A teoria neo-institucional refere-se ao exercício de pressões homogeneizadoras por estados e outros atores políticos relevantes como isomorfismo coercivo. A coerção internacional ocorre se "atores internacionais poderosos influenciam, de forma direta, as escolhas políticas dos governos, ou quando tais atores alteram os resultados da dinâmica política interna de um país ao intervirem na formação de coalizões domésticas" (Henisz, Zelner e Guillén, 2004). A coerção 


\section{Dawisson Belém Lopes}

direta implica que os grupos ou partidos domésticos simplesmente aquiesçam às pressões internacionais - as condicionalidades impostas por bancos multilaterais de crédito internacional enquadrar-se-iam nessa categoria. Vasta literatura sobre a coerção internacional aponta que o papel de agências multilaterais - controladoras dos recursos financeiros de que carecem muitos dos países pobres da América Latina - goza de legitimidade, e até do apoio, dos estados ricos - os que mais contribuem para o seu sustento. Ao estudar as barganhas entre "emergentes" e o Fundo Monetário Internacional -, no início dos anos 1980, Kahler constatava:

"Para o FMI, os win-sets eram freqüentemente definidos por fórmulas; mas por trás dessas fórmulas estão os interesses dos principais integrantes do Fundo, os países industrializados [...] por um lado, durante os anos 1980, um acordo que fosse percebido como muito 'frouxo' em suas condicionalidades dificilmente sobreviveria ao escrutínio da direção do FMI. Por outro lado, países específicos, como os Estados Unidos da América, também tentariam modificar os programas [de reformas estruturais do Estado] que fossem vistos como excessivamente duros com os seus clientes favoritos" (Kahler, 1993:389-390, tradução do autor).

A coerção indireta presume a existência de mais de uma alternativa política à maneira como se proceder com as reformas neoliberais. Se os grupos políticos em enfrentamento no interior de um determinado país manifestarem posições diversas, então a intervenção de uma terceira parte - uma parte alienígena - poderá operar como o fiel da balança (Henisz, Zelner e Guillén, 2004; Cardoso e Faletto, 2004:37-52).

As constrições internacionais a que estão sujeitos os países da periferia internacional são variadas. Choques econômicos, anota Haggard (1990), costumam ter efeitos deletérios para as economias orientadas para fora, e efeitos ambíguos para as voltadas para dentro. O tamanho do país é fundamental nessa equação, argumenta Ricupero: "países monstros", como Brasil, Índia e Rússia, têm uma inserção na economia internacional difícil de coordenar; ao passo que "países de intermediação", como Bélgica e Cingapura, se inserem naturalmente, e têm no comércio exterior parte expressiva de seu PIB (Ricupero, 2002). Para Lijphart, no entanto, essa relação é ambivalente: os países grandes têm um poder maior nas relações internacionais - que pode ser usado na obtenção de benefícios econômicos para os seus cidadãos; por outro lado, maior influência internacional significa maior responsabilidade, 
materializada, muitas vezes, em maiores despesas (especialmente, as de propósito militar) (Lijphart, 2003:293-308). As contingências do poder na cena internacional também se mostram decisivas: Haggard percebe que, enquanto o leste asiático era compelido a desenvolver-se após a Segunda Guerra Mundial, a América Latina, geograficamente próxima do "grande arco de contenção americano", não constituía ameaça estratégica e, portanto, não gerava estímulos para o aporte desenvolvimentista da potência capitalista (Haggard, 1990:31-32).

Sobre o papel que os Estados Unidos devem desempenhar na economia internacional contemporânea, há visões discrepantes: Robert Gilpin entende que, historicamente, sempre que houve crescimento sustentado da economia mundial, se observou a liderança de uma grande potência (Pax Britannica no pré-Primeira Guerra; Pax Americana no pós-Segunda Guerra). Gilpin adverte que, se quisermos um mundo economicamente próspero, deveremos nos submeter à "hegemonia benigna" dos Estados Unidos; estes, por seu turno, também devem estar dispostos a arcar com a liderança econômica global. Gilpin percebe, não obstante, que, a partir dos anos 1970, o caminho tomado pelos americanos foi a deserção: o abandono do padrão-ouro (1971) e as crises do petróleo $(1973,1979)$ redundaram em abalos na capacidade (e no ânimo) estadunidense de liderar e coordenar a economia globalizada. Por isso, temos assistido, com tanta freqüência, às crises de liquidez mundo afora - em particular, na América Latina (Gilpin, 2004). Outro economista, Dani Rodrik, rejeita a versão. Alega, acompanhando o curso evolutivo da economia internacional, que o Welfare State de estilo europeu dominou a cena nos anos 1970; o Japão tornou-se o modelo a ser emulado nos anos 1980; e que os anos 1990 favoreceram o capitalismo livre e desregulado da matriz anglo-saxã. Logo, "A evidência da segunda metade do século XX é a de que nenhum desses modelos domina claramente os outros. Seria um erro alçar o capitalismo de estilo norte-americano como modelo para o qual o resto do mundo deve convergir" (Rodrik, 2002:75).

O raciocínio emulatório é considerado, por alguns estudiosos da temática, como a principal chave explicativa para as reformas neoliberais na América Latina. O isomorfismo mimético refere-se à "tendência de os atores buscarem legitimidade pela emulação do comportamento ou das práticas de outros atores" (Henisz, Zelner e Guillén, 2004). A emulação (ou mimetismo) se dá quando há incerteza acerca da efetividade de certas práticas e/ou políticas, ou quando o leque de alternativas 


\section{Dawisson Belém Lopes}

possíveis torna-se tão amplo, que é difícil para o agente racional apreender as variáveis necessárias para a tomada de decisão. Assim, costuma-se recorrer à imitação dos "bem-sucedidos". Além disso, a própria estrutura social pode induzir o comportamento mimético (idem). No âmbito das relações internacionais, é razoavelmente freqüente a imitação, por parte de estadistas, das opções políticas feitas por seus homólogos. Estudando o caso do sindicalismo brasileiro e as relações trabalhistas firmadas durante os anos 1990, Adalberto Cardoso pondera: “Não foi a política, sob Fernando Henrique Cardoso, a 'arte do possível'? Não estavam os fins dados de antemão pela globalização? Então a política do possível restringiu-se à otimização dos meios e, em lugar de ser o momento da elaboração e negociação de projetos de sociedade, limita-se ao mimetikós adaptativo" (Cardoso, 2003:26).

North reivindica que a mera transferência de regras formais, políticas e/ou econômicas, das bem-sucedidas economias ocidentais de mercado livre para o Terceiro Mundo, não é condição suficiente para o desenvolvimento. Antes, as instituições e os sistemas de crença precisam mudar conjuntamente para que as reformas surtam efeito, uma vez que são os modelos mentais dos atores que modularão as suas escolhas (North, 1998:255). Mas não se pode desconsiderar, ainda assim, o fascínio que as visões de mundo, as teorias intelectuais e os referenciais simbólicos (em oposição aos aspectos materiais) forjados nos centros culturais do mundo desenvolvido costumam exercer sobre os tomadores de decisão latino-americanos (Campbell e Pedersen, 2001:264).

Há os que preferem abordar a questão das reformas do Estado latino-americano de uma perspectiva estritamente racionalista ${ }^{5}$. Os teóricos da barganha, reconhecendo, no que respeita às reformas estruturais na América Latina, a similaridade de rotas adotadas pelos países ao longo dos anos 1980-2000, e, ainda assim, alegando a persistência de diferenças institucionais (formais e funcionais) entre eles, postulam que a "assimetria de recursos entre os atores envolvidos em dado contexto social determina, por meio das repetidas interações entre eles, a resultante modelagem institucional" (Knight, 2001:42, tradução do autor). Esse modelo de interações reiteradas entre os atores políticos, geralmente pensado para o ambiente doméstico, é transplantado para a arena política internacional. A assimetria de recursos entre os países do Norte capitalista e os do subcontinente latino-americano ajudaria a compreender o andamento do processo reformista. A similaridade de rotas seguidas por Uruguai, Brasil e Honduras seria, portanto, o sub- 
produto do hiato de forças entre países desenvolvidos e países pobres, dotados de menos recursos.

Os teóricos contratualistas valem-se das tradicionais premissas da racionalidade econômica, na tentativa de prover explicações para as reformas estruturais da América Latina. Ao identificarem incentivos econômicos internacionais (minimização dos custos transacionais) à adoção de um determinado padrão competitivo (liberalização econômica), atores estatais (racionais) confluiriam, voluntariamente, para as reformas neoliberais (Knight, 2001). Hall e Soskice (2001:41) concedem que as molduras institucionais das economias liberais de mercado proporcionam às empresas capitalistas melhores condições para a inovação radical. Logo, a busca por "vantagens institucionais comparativas" poderá ser a força a propelir os estados no rumo dos esforços de reforma. North, ao discorrer sobre as mudanças institucionais, afirma que a forma como se concretizarão as organizações de um dado contexto social tenderá a refletir as oportunidades propiciadas pela matriz institucional. Consoante seu raciocínio, se uma determinada matriz institucional recompensa a prática da pirataria, por exemplo, as organizações orientadas para a pirataria abundarão (North, 1998:249).

Ao final, parece, entretanto, que mesmo os que focalizam preferencialmente os aspectos domésticos da política latino-americana para explicar as reformas neoliberais não escapam de um olhar internacionalista. Ikenberry resume, sobre o movimento maciço de privatizações: "programas de privatização em países desenvolvidos e em desenvolvimento podem ser entendidos apenas com uma apreciação do contexto internacional" (Ikenberry apud Henisz, Zelner e Guillén, 2004, tradução do autor). Mesmo os que não percebem na globalização corrente qualquer traço revolucionário (Gilpin, 2004; Grahame e Hirst, 1998) convêm em que, pesados os fatores, se afigura ingenuidade crer na mera autodeterminação reformista dos países latino-americanos. Condicionantes internacionais concorreram para a nova moldagem do Estado latino-americano de fins do século XX. Concordar com tal asserção não implica a crença no "fim do Estado", no "fim da política", no "fim da história", no "fim da diversidade cultural" ou em outros tipos de fatalismo. Muito pelo contrário. Em primeiro lugar, condicionar não quer dizer determinar. Afirma-se que as relações econômicas internacionais têm sido o condicionante de maior peso - mas não o único - para a reforma do Estado na América Latina. A economia internacional é o elemen- 
to comum aos três Estados - Uruguai, Brasil e Honduras - que mais provavelmente pode explicar a concertação dos seus movimentos reformistas - apesar das diferenças históricas, geográficas, étnicas, demográficas, culturais, sociais e econômicas que ostentam entre si. Mas seria um erro apostar na irrelevância do Estado contemporâneo em face da economia internacional, ou na irreversibilidade do atual quadro político internacional. Estados têm reagido, de diferentes maneiras, aos desafios com que são defrontados - isso talvez esclareça, para alguns, as diferenças nas formatações institucionais que têm resultado do processo de reformas neoliberais - na América Latina e no mundo.

Em segundo lugar, é bastante provável que todo o alarde dos que apregoam o excepcionalismo desta globalização corrente não encontre arrimo na história. Como Gilpin (2004) assinala, em vários de seus aspectos, a atual onda mundializante da economia não supera aquela ocorrida em fins do século XIX. O mesmo Gilpin reconhece que o sistema econômico internacional sempre teve uma estrutura muito hierárquica. Não é novidade de nossos tempos. Em se tratando de América Latina, quando se analisam as estatísticas socioeconômicas concernentes às suas duas últimas décadas, vem à tona o lugar relativamente periférico ocupado pelo subcontinente nas relações internacionais. É nítida a estreiteza da margem de manobra dos líderes latino-americanos na cena internacional. Ao expormos tal posição, não estamos, por assim dizer, descobrindo a roda (ou a América!).

Finalmente, em terceiro lugar, qualquer que seja a hipótese adotada para tentar explicar a origem das reformas neoliberais na América Latina (coerção não-resistida, emulação ou estratégia racional adaptativa), importante é notar que todas remetem para fora dos limites do território nacional. Corroborar com a nossa primeira hipótese (a de que as reformas neoliberais na América Latina se submeteram à lógica das relações econômicas internacionais) requer a percepção de que os Estados nacionais - quaisquer que sejam - ocupam um lugar no mundo ou seja, são as partes integrantes de um todo bastante amplo - e que, portanto, não estão imunes às forças que operam no seu entorno.

\section{A QUALIDADE DA DEMOCRACIA LATINO-AMERICANA}

A lógica que estrutura as relações econômicas internacionais, como já debatido em linhas pregressas, tem-se mostrado, na maior parte dos 
casos, um entrave à consolidação da democracia latino-americana. Como é sabido, o movimento de redemocratização, na maioria dos países da América Latina, deu-se em concomitância com as reformas estruturais do Estado - sob a égide de forças da economia internacional. E, conforme se sustenta, a lógica que flui das relações econômicas internacionais tem ocasionado déficit de legitimidade social do Estado na América Latina. Tem-se batizado o referido fenômeno de "déficit democrático".

Pergunta-se: se, em regimes democráticos, o demos (povo) é quem escolhe como e onde alocar os recursos públicos, por que o déficit de legitimidade social do Estado persistiu - e até se agravou - no contexto das últimas duas décadas - já redemocratizadas - na América Latina? Por que as classes populares não puderam - pelo exercício de suas prerrogativas democráticas - concretizar anseios básicos, respeitantes à cidadania e ao bem-estar?

Para seguir adiante com a argumentação - que visa desnudar a relação estabelecida entre as forças econômicas internacionais e a democracia na América Latina -, submete-se ao crivo do interlocutor a segunda hipótese que estrutura o estudo. Convém, antes, observar como o PNUD tem avaliado a progressão histórica da democracia na América Latina. Adicionalmente, interessa-me conhecer a posição dos cidadãos latino-americanos em relação à democracia no subcontinente.

A Tabela 7 mostra a evolução de um quadro generalizado de autoritarismo na América Latina, na segunda metade dos anos 1970, para a democratização (quase) absoluta, atingida já no início da década de 1990 e perpetuada até os dias que correm, em Uruguai, Brasil e Honduras. A ascendência da curva é hiperbólica: segundo o PNUD, a América Latina ostentava, em 1977, um Índice de Democracia Eleitoral - IDE médio de 0,28; 25 anos mais tarde, em 2002, esse mesmo índice galgou o 93응 percentil da escala - e, não fossem alguns episódios ou configurações pontuais em Chile, Colômbia, Equador e Venezuela, estaríamos, os latino-americanos, muito próximos do IDE máximo. A Tabela 8, por sua vez, sugere a aprovação majoritária do regime democrático - em oposição ao regime autocrático - pelo povo da América Latina. Quarenta e três por cento dos entrevistados declararam-se democratas convictos, enquanto apenas $26,5 \%$ assumiram a posição reversa, a de não-demo- 
cratas. Em Uruguai, Brasil e Honduras, os democratas voltaram a superar os não-democratas.

Tabela 7

Índice de Democracia Eleitoral (IDE)*

\begin{tabular}{l|c|c|c|c|c|c|c}
\hline País/Região & $\mathbf{1 9 6 0}$ & $\mathbf{1 9 7 7}$ & $\mathbf{1 9 8 5}$ & $\mathbf{1 9 9 0}$ & $\mathbf{1 9 9 5}$ & $\mathbf{2 0 0 0}$ & $\mathbf{2 0 0 2}$ \\
\hline Uruguai & 1,0 & 0,0 & 0,75 & 1,0 & 1,0 & 1,0 & 1,0 \\
Brasil & 0,69 & 0,26 & 0,39 & 1,0 & 1,0 & 1,0 & 1,0 \\
Honduras & 1,0 & 0,0 & 0,92 & 1,0 & 1,0 & 1,0 & 1,0 \\
América Latina & 0,58 & 0,28 & 0,69 & 0,86 & 0,88 & 0,91 & 0,93 \\
\hline
\end{tabular}

Fonte: PNUD (2004b).

*Índice elaborado a partir da observância de quatro elementos: (a) sufrágio universal; (b) eleições limpas; (c) eleições livres; e (d) acesso a cargos públicos via eleições.

Tabela 8

Apoio Declarado à Democracia

$(\%)$

\begin{tabular}{l|c|c|c|c}
\hline País/Região & $\begin{array}{c}\text { Democratas } \\
\text { (A) }\end{array}$ & $\begin{array}{c}\text { Ambivalentes } \\
\text { (B) }\end{array}$ & $\begin{array}{c}\text { Não-Democratas } \\
\text { (C) }\end{array}$ & $\begin{array}{c}\text { Indicador } \\
\text { de Maioria } \\
\text { (A)/(B)+(C) }\end{array}$ \\
\hline Uruguai & 71,3 & 14,1 & 14,6 & 2,48 \\
Brasil & 30,6 & 42,4 & 27,0 & 0,44 \\
Honduras & 46,2 & 37,1 & 16,7 & 0,86 \\
América Latina & 43,0 & 30,5 & 26,5 & 0,76 \\
\hline
\end{tabular}

Fonte: PNUD (2004b).

A primeira impressão a ser retida pelo interlocutor desavisado é a de um quadro democrático extremamente animador. Já um segundo olhar nas referidas tabelas pode revelar detalhes perturbadores. $\mathrm{O}$ IDE, índice empregado pelo PNUD na confecção da Tabela 7, refere-se tão-somente à dimensão eleitoral da democracia. Isto é: à concepção de democracia schumpeteriana; à capacidade de formar governos pela via do sufrágio universal, sem pressões que venham distorcer os resultados dessa prática. O IDE atém-se à análise das formalidades eleitorais que envolvem os pleitos democráticos na América Latina. Não é pouca coisa, alguns dirão - especialmente, se contrastamos os anos 1970 e os anos 2000. Mas fique bem claro: os indicadores do PNUD não levam em conta as variadas dimensões do fenômeno democrático. $\mathrm{O}$ IDE/PNUD é um índice unidimensional - e, por isso, bastante limitado. No que respeita à Tabela 8, é importante notar que o espectro do 
comportamento político do cidadão latino-americano abrange não apenas os democratas e os não-democratas. Há espaço também para os ambivalentes, ou seja, aqueles que não nutrem preferência específica por um determinado tipo de regime político, interpolando-se aos democratas e não-democratas. Cerca de $30 \%$ de toda a população latino-americana diz-se ambivalente quanto à modalidade do regime político a se exercer em seu país. O dado denota a progressiva despolitização (na via institucional) da política na América Latina. Os índices de ambivalência ultrapassam os 37\% em Honduras e atingem um teto de $42 \%$ no Brasil ${ }^{6}$. Atinente aos indicadores de maioria democrática, cumpre notar que, à exceção do Uruguai (cuja maioria democrática é cerca de 2,5 vezes maior do que o somatório das minorias não-democráticas / ambivalentes), todos os demais países latino-americanos pesquisados ou fazem maiorias democráticas estreitas ( $x \leq 1,2$; casos de Argentina, Costa Rica, México, Peru e Venezuela), ou não conseguem constituir maiorias democráticas absolutas ( $x \leq 1,0$; casos de Bolívia, Brasil, Colômbia, Chile, Equador, El Salvador, Guatemala, Honduras, Nicarágua, Panamá, Paraguai e República Dominicana). Isso se reflete no indicador de maioria democrática da América Latina, de 0,76-ou seja: o número de "democratas" declarados no subcontinente é cerca de três quartos do número de "não-democratas" + "ambivalentes" declarados. Em outras palavras: não somos um subcontinente cuja maioria simples da população externe a preferência pela democracia como regime político.

Se, em termos quantitativos, não fazemos maioria democrática simples na América Latina, em termos qualitativos, o cenário não é mais promissor. Quase 30\% da população latino-americana não soube responder ou não respondeu à pergunta "o que significa a democracia?"; em Honduras, esse número chegou a 35\%; e, no Brasil, a 63\% da população entrevistada. "Uma grande quantidade de latino-americanos não tem clareza sobre o significado da democracia. Para muitos latino-americanos, a democracia não significa algo que possam expressar em palavras" - analisa Zovatto (2002:31-33, tradução do autor). De acordo com levantamento feito pela instituição chilena Latinobarómetro, em 2002, metade da população latino-americana não se incomodaria com o fato de um governo "não-democrático" (concebido em oposição a um governo "democrático") ascender ao poder. Em Honduras, registra-se uma maioria de 53\% de cidadãos indiferentes a uma eventual ascensão de não-democratas ao poder. No Brasil, $62 \%$ dos entrevistados alegaram não se importar se governos autoritários, em algum 


\section{Dawisson Belém Lopes}

tempo futuro, retornassem ao poder. Contribuem para a fragilização da noção de democracia latino-americana os dados apresentados, na seqüência, pelo PNUD (2004b): 58,1\% dos cidadãos latino-americanos concordariam se, em algum momento, o presidente desrespeitasse o imperativo da lei (rule of law), o fundamento do Estado democrático de direito; e 56,3\% acreditam que o desenvolvimento toma precedência sobre a democracia - o que não constitui grande surpresa -, mas $54,7 \%$ afirmaram que chegariam a apoiar regimes autoritários que trouxessem o desenvolvimento - aqui, sim, temos configurada uma ameaça à integridade democrática na América Latina, tendo-se em vista os insatisfatórios indicadores econômicos das duas últimas décadas, já exaustivamente mencionados neste artigo. Aproximadamente $40 \%$ da população crê possível prescindirmos de partidos políticos e do Congresso nacional em democracias, e $36 \%$ concordaria se o presidente viesse governar sem partidos políticos e o Congresso - o que não deixa de traduzir a baixa estima dos cidadãos para com tais instituições da democracia representativa na América Latina; 37\% apoiaria atitudes presidenciais que lhes tolhesse a liberdade de expressão, impondo a censura, bem como $37 \%$ da mostra concordaria com o recurso presidencial à força para a manutenção da ordem ${ }^{7}$. Por fim, um dado que denuncia, se nada mais, certo apelo ideológico da relação entre democracia e desenvolvimento: apenas $25,1 \%$ da mostra acredita possível o desenvolvimento socioeconômico apartado da democracia. $\mathrm{O}$ restante, três quartos da mostra, entende que a democracia é indispensável para o desenvolvimento. Pergunta-se: de onde vem essa convicção dos $75 \%$ da amostragem? De quais indícios formais?

O descompasso existente entre a idéia de democracia e as instituições democráticas na América Latina ajuda a minar a noção de "democracia latino-americana". Muito embora $43 \%$ dos cidadãos latino-americanos se digam cultores da democracia, os níveis de confiança da população nas instituições democráticas são, em aparente paradoxo, baixos. A média aritmética dos níveis de confiança nas três principais instituições da democracia representativa latino-americana - a Presidência, o Congresso e os partidos políticos - foi de apenas 19\%, em 2002. E esses índices são declinantes: entre 1996 e 2002, a Presidência ficou 14\% mais desacreditada; o Congresso, $4 \%$; os partidos políticos, $6 \%$. Instituições tipicamente não-democráticas, como a Igreja, a televisão e as Forças Armadas, gozam de um relativamente alto prestígio entre os cidadãos latino-americanos, atingindo percentuais de confiabilidade expressivos (entre 1996-2002: 75\%, 46\% e 40\%, respectivamente). O exemplo 
hondurenho é eloqüente: ainda em 2001, a confiança nos militares excedia - e muito - os índices de confiança nos políticos e nas instituições-chave da democracia (PNUD, 2001:51). Recentemente, no entanto, o quadro deu mostras de reversão (PNUD, 2004b).

A Tabela 9 ilustra o que Susan Stokes batizou de policy switches, isto é, o não-cumprimento de promessas de campanha durante o exercício de mandatos eletivos, na América Latina (ou, simplesmente, "violações de mandato"). Quase 65\% dos cidadãos latino-americanos crêem que os políticos mentem para ganhar as eleições - $58 \%$ no Uruguai; $61 \%$ em Honduras; $78 \%$ no Brasil. E quantos são os que afirmam que os políticos realmente cumprem as suas promessas de campanha? Na média latino-americana, 2,3\% da população ( $4 \%$ em Honduras, 1,3\% no Brasil). Stokes entende que as violações de mandatos não acarretam maior dano à democracia representativa, uma vez que continuarão a existir formas auxiliares de accountability por meio das quais o cidadão poderá fazer o seu controle democrático. Agarrar-se ao conjunto de promessas eleitorais não é a única forma de um político fazer representar os interesses da população - diz Stokes. Mandatos têm sido violados na América Latina porque os políticos antecipam "a prestação de contas do fim do mandato" (Stokes, 1999:126, tradução do autor). Stokes conclui: "Violações de mandato não são inconsistentes com a representação em sentido estreito. Mas devem causar preocupação no tocante à qualidade das democracias em que elas se fazem endêmicas" (idem:128, tradução do autor). Diferentemente, entendo ser a implicação dessa postura assumida por políticos latino-americanos bastante

Tabela 9

Promessas Eleitorais

(Pergunta: "Os Governantes Cumprem as Suas Promessas Eleitorais?")

(\%)

\begin{tabular}{l|c|c|c|c|c|c}
\hline País/Região & Sim & $\begin{array}{c}\text { Não, Por- } \\
\text { que Igno- } \\
\text { ram a } \\
\text { Complexi- } \\
\text { dade dos } \\
\text { Problemas }\end{array}$ & $\begin{array}{c}\text { Não, Por- } \\
\text { que Apare- } \\
\text { cem Pro- } \\
\text { blemas } \\
\text { Mais } \\
\text { Urgentes }\end{array}$ & $\begin{array}{c}\text { Não, Por- } \\
\text { que o “Sis- } \\
\text { tema" Não } \\
\text { os Deixa } \\
\text { Cumprir }\end{array}$ & $\begin{array}{c}\text { Não, Por- } \\
\text { que Men- } \\
\text { tem para } \\
\text { Ganhar as } \\
\text { Eleições }\end{array}$ & $\begin{array}{c}\text { Outras } \\
\text { Respostas }\end{array}$ \\
\hline Uruguai & 2,3 & 7,7 & 16,6 & 13,5 & 58,0 & 1,9 \\
Brasil & 1,3 & 5,1 & 3,3 & 10,5 & 78,6 & 1,2 \\
Honduras & 4,0 & 13,1 & 12,6 & 7,9 & 61,1 & 1,4 \\
América Latina & 2,3 & 10,1 & 9,6 & 11,5 & 64,7 & 1,7 \\
\hline
\end{tabular}

Fonte: PNUD (2004b). 


\section{Dawisson Belém Lopes}

grave: o voto do cidadão médio, na América Latina, passa a ser concebido como destituído de valor prático, por não ser ele, o cidadão, quem definirá os rumos efetivos da ação governamental. E o pior: o cidadão ganha plena consciência desse processo. A tendência, em médio/longo prazo, é de que os níveis de desconfiança política se elevem, até o limite do que é necessário para a manutenção da coesão social. Após esse limite, de duas, uma: ou se muda a forma de fazer a política ${ }^{8}$, ou a democracia representativa latino-americana estará correndo sério risco (Paramio, 2002b:11).

Algumas hipóteses são aventadas por Paramio para explicar a desvalorização de nossa política democrática: (a) na América Latina, apenas os resultados práticos de um governo são levados em conta na avaliação da democracia, e não o seu mérito como regime político. Sendo assim, quando não se vêem os resultados, contesta-se a democracia; (b) a crescente personalização da política na América Latina - o que alguns chegaram a considerar como o renascimento do caudilhismo; (c) o peso da tradição latino-americana de patrimonialismo e clientelismo, obstando o florescimento da cultura democrática; (d) a percepção generalizada da crise na América Latina e a associação com o processo de redemocratização; (e) a percepção de que, diante das forças da globalização, pouco podem os governos nacionais; (f) a enorme frustração dos cidadãos com os resultados das reformas estruturais na América Latina, que prometiam ser a tábua de salvação do subcontinente (idem:5-9).

Investiga-se, adiante, a percepção da justiça social na América Latina. Em um espectro que vai de 1 (muita injustiça social) a 4 (muita justiça social), a média latino-americana foi de 1,82. Ou seja: percebemo-nos um subcontinente socialmente injusto. A autopercepção da injustiça social na América Latina é consistente com os altos coeficientes de Gini registrados no interior dos países. Importante, contudo, é notar que em Honduras, país em que $80 \%$ dos habitantes sobrevivem com renda menor que US\$ 1 / dia, a percepção da justiça social é $10 \%$ mais positiva do

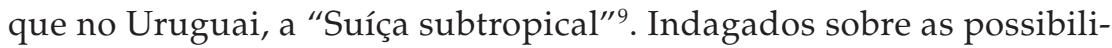
dades de um pobre fazer valer os seus direitos no seu país, $78 \%$ dos uruguaios, 79,5\% dos brasileiros e 75,8\% dos hondurenhos abordados responderam negativamente. No Brasil e em Honduras, a assertividade da denúncia de desigualdade legal por parte da população entrevistada foi maior: respectivamente, $49 \%$ e $44 \%$ dos entrevistados afirmaram que um pobre nunca faz valer os seus direitos no seu país (contra 25\% dos uruguaios) (PNUD, 2004b) ${ }^{10}$. 
Entre 1996 e 2002, apenas um terço da população se disse "satisfeita" ou "muito satisfeita" com o regime democrático. Mas o desvio-padrão é alto: no Brasil, o índice de aprovação caiu para 22\%; no Uruguai, elevou-se a $60 \%$. É bastante possível que, para a configuração desse quadro, interfira fortemente o vetor da cultura política de cada país, assim como as questões referentes à conjuntura socioeconômica. A tendência se manteve mais ou menos constante no agregado de países latino-americanos: entre 1999 e 2002, declinou a satisfação com a democracia, de $35 \%$ para $32 \%$ - exceção feita a Honduras, onde os níveis de satisfação com a democracia se ampliaram em 17 pontos percentuais no referido período (idem).

Apesar de professarem fé no ideal da democracia, os latino-americanos acabam por enjeitar a sua encarnação prática. Inquiridos sobre quais seriam os grupos que mais exerceriam poder em seus respectivos países, uruguaios, brasileiros e hondurenhos responderam: empresas e mercado financeiro. Em 2001, esse índice em pouco ultrapassava os $42 \%$ nos três países. Contudo, em 1996 - portanto, no "olho do furacão" das reformas estruturais -, 52,2\% dos uruguaios, 63,4\% dos hondurenhos e $65,5 \%$ dos brasileiros apontavam as forças do mercado como as dominantes na cena política doméstica - logo, responsáveis, em larga medida, por todo o movimento reformista naqueles países. Confrontados pela mesma pergunta, líderes políticos latino-americanos não divergiram de seus governados: quase $80 \%$ afirmaram que os grupos econômicos e o setor financeiro são quem exerce o poder fático na América Latina. Dentre os poderes constitucionais, apenas 36,4\% dos cidadãos entrevistados citaram o "Poder Executivo"; só 12,8\% responderam "Poder Legislativo" e 8\%, "Poder Judiciário". Dentre os fatores externos, os Estados Unidos da América mereceram maior número de menções (quase 23\% dos entrevistados elegeram essa resposta). Se os dados apresentados em defesa da primeira hipótese que estrutura o corrente trabalho já sugeriam que a política na América Latina é constrangida pelas relações econômicas (internacionais), a percepção dos cidadãos comuns e dos governantes não difere muito da nossa (idem).

\section{GLOBALIZAÇÃO, ONDA DEMOCRÁTICA E AUTONOMIA DO INDIVÍDUO}

Algumas questões restam. Por que a democracia latino-americana é formalista, pouco substanciosa? Por que a abordagem procedimentalista da democracia - aquela em que as liberdades e prerrogativas do indivíduo (transformadas em "procedimentos democráticos") têm primazia sobre as questões de democracia dita substantiva (por exem- 


\section{Dawisson Belém Lopes}

plo: solidariedade, igualdade, justiça social) - encontrou terreno fértil neste subcontinente? Por que, do embate clássico entre a cidadania civil e a cidadania social, a primeira concepção tem saído vitoriosa, na América Latina?

Sobre a controvérsia entre procedimentalistas e substantivistas, Przeworski apresenta a versão de que, se a democracia é um sistema em que os resultados parecem sempre incertos, nenhum "conteúdo social" lhe pode ser incorporado como objetivo - sob pena de que compromissos prévios com valores, como a busca da igualdade, da justiça ou do bem-estar coletivo, acarretem a perda da "incerteza ex ante", elemento constitutivo dos regimes democráticos (Przeworski, 1994:54). O que escapa à formulação de Przeworski é o fato de que uma abordagem procedimentalista também faz, necessariamente, compromissos com valores ex ante. Ao priorizarem práticas como o sufrágio universal, direitos como a livre concorrência e a livre expressão, além da proteção do indivíduo contra a violência arbitrária, os procedimentalistas nada mais fazem do que "empalhar" os seus valores, tornando-os procedimentos. A inferência lógica: enquanto tais, procedimentalistas são substantivistas. Ao transformarem os seus procedimentos em meios, eles não escapam de um compromisso normativo prévio, uma vez que, na política, não há meios neutros. Não há meios que não sucedam princípios, que não antecedam fins.

$\mathrm{Na}$ interface da economia e da política, Assies, Calderón e Salman (2002:57) sustentam que a perspectiva focalizada no Estado e em aspectos formais e legais constitui uma camisa-de-força que obscurece aspectos importantes do problema, distorcendo a realização de uma cidadania plena. Patrício Silva, por sua vez, defende que a orientação ao livre-mercado, que se imprimiu às reformas estruturais latino-americanas, vai de mãos dadas com o conceito procedimental de democracia, em que a tomada de decisões no nível macro é delegada a um grupo de tecnocratas especialistas, em sintonia com os seus pares das agências multilaterais de crédito (apud Assies, Calderón e Salman, 2002). O que Silva propõe é a visão de que a tecnocracia e a plutocracia são formas degenerativas em que se tem metamorfoseado a democracia (procedimentalista) latino-americana. Vista sob o prisma da tríade marshalliana dos direitos cidadãos, as reformas neoliberais privilegiam os direitos civis, designando um papel operacional para a sociedade civil. Em contraposição, os direitos políticos são encampados de forma restrita e procedimental, como uma abreviação dos direitos soci- 
ais. Privilegia-se a responsabilidade do indivíduo para com o seu bem-estar e de seus dependentes. Não só os mercados se desregulamentam, senão as próprias políticas sociais se restringem e se subsumem à lógica dos mercados (idem).

Zovatto, investigando o conteúdo que se associa aos signos democráticos na América Latina, encontrou que o conceito de democracia que têm os cidadãos latino-americanos está centrado nos valores da liberdade e das eleições. Ao indicarem os conteúdos mais significativos embutidos na idéia de uma democracia, $35 \%$ associaram-na à liberdade; $10 \%$, à igualdade/justiça; $6 \%$, ao direito ao voto; e $5 \%$, ao governo para o povo. No tocante às práticas mais importantes do regime democrático, 27\% apontaram as eleições regulares, limpas e transparentes; $16 \%$, uma economia que assegure a dignidade; $15 \%$, a igualdade legal; e $15 \%$, a liberdade de expressão. Ainda, latino-americanos tendem a conceber a democracia de uma maneira "churchilliana" - isto é, como o menos ruim dentre os sistemas políticos conhecidos. Sessenta e oito por cento dos entrevistados declararam que, apesar de todos os problemas, a democracia é o melhor sistema de governo; e 75\%, na contramão, afirmaram que a solução dos problemas de seus países não depende da democracia (Zovatto, 2002:31). Pelo que se pode observar, a configuração procedimentalista e civilista da cidadania latino-americana, com priorização das liberdades e direitos individuais, também parte, em boa medida, dos desejos e crenças dos seus próprios cidadãos.

Há cabimento falarmos de um indivíduo politicamente autônomo na América Latina? O tema da autonomia é abordado nos escritos de Reis (2000) e encerra dois sentidos: (a) uma afirmação espontânea do "eu", em que o ideal envolvido é o de dar vazão de forma irrefletida a impulsos e motivações de qualquer sorte; $\mathrm{e}$ (b) o autocontrole, em que o principal elemento é a reflexividade com respeito aos motivos e objetivos próprios e suas relações com objetivos outros. As noções de autonomia expostas são, em larga medida, incompatíveis entre si. Reis entende a reflexividade e a lucidez como componentes indispensáveis para a expressão autêntica do "eu"11. O indivíduo individuado opõe-se ao indivíduo não-reflexivo, completamente imerso na sociedade. A ação racional é prerrogativa desse indivíduo individuado - e não poderá ser experimentada pelo indivíduo não-reflexivo. $\mathrm{O}$ verdadeiro democrata é, nesse sentido, o indivíduo "autônomo", na segunda acepção fornecida por Reis (idem) - pois é quem poderá identificar os valores que per- 


\section{Dawisson Belém Lopes}

meiam a política de seu tempo e, só então, tomar partido, fazer as suas escolhas. Em face do postulado e à luz dos dados resgatados e discutidos neste artigo, há motivo para duvidar da autonomia política do "cidadão médio" latino-americano ${ }^{12}$.

E, afinal, o atual estágio das relações internacionais contribui para a afirmação ou para o malogro das práticas democráticas na América Latina? Qual a relação mais provável que se estabelece entre a globalização ora em curso e o processo de democratização latino-americana?

Os ajustes da mutante ordem global incluem a absorção de algumas das funções do Estado por mecanismos transnacionais. Estreitam-se, em decorrência, as possibilidades de ação política para a construção de alternativas democráticas. Estados nacionais periféricos estão submetidos à dinâmica mundializante das relações internacionais, e aparentam não poder fazer muito para resistir a ela. Faliu o estritamente "interno"; sobrepôs-se o "internacional" - sem anular o Estado, contudo. Não restou na política internacional uma Albânia dos anos de Guerra Fria, uma comunidade política que possa permanecer hermeticamente fechada às relações internacionais. E os problemas dessa integração global não-resistível acumulam-se. Hopenhayn (1998) destaca a contradição entre a crescente integração simbólica, pelos novos sistemas de comunicação, e a exclusão de muito daquilo que prometem os meios de massa. Os benefícios concentram-se em poucas mãos. Calderón (2002) percebe que as promessas não cumpridas da globalização exercem fortes pressões destrutivas sobre a democracia. Chega a falar em uma "bomba de tempo", ou seja, a inconsistência das promessas de políticos (democraticamente eleitos) e a frustração das expectativas materiais dos eleitores provocariam a hostilização das instituições e práticas democráticas. Falk (2000) argumenta que as elites estatais adotam uma perspectiva cada vez mais desterritorializada, o que contribui para o debilitamento do sentido de identificação nacional - a perda de cultura cívica. Por outro lado, a resistência oferecida por civilizações não-ocidentais aos valores tipicamente ocidentais da democracia e da cidadania pode impedir a livre difusão desses ideais. Falk vislumbra, para além das formas democraticamente regressivas de apropriação da globalização, formas progressivas também: a formação de uma agenda política do "Sul"; a formação de alianças internacionais de países em desenvolvimento; a atuação concertada de países pobres em foros multilaterais (todos os três movimentos descritos indicam o fortalecimento da lógica democrática no plano internacional, a despeito da 
globalização) (Assies, Calderón e Salman, 2002; Paramio, 2002a; 2002b).

Boschi tem propugnado que o contexto internacional pouco contribui para a consolidação da democracia na América Latina - principalmente a partir da conjuntura de violência, terrorismo internacional e intervencionismo unilateral que se instaurou no cenário internacional desde o início da era George W. Bush (Boschi, 2004a; 2004b). A visão é compatível com aquela oferecida pelo PNUD (2004a) sobre a democracia na América Latina - que, apesar de poupar a gestão do presidente Bush de críticas diretas, traça a mesma correlação entre a proliferação da violência na cena internacional e a diminuição dos graus de liberdades de que desfrutam os cidadãos após o episódico 11 de setembro. Em um outro diapasão, o sociólogo português Boaventura de Sousa Santos pondera que a globalização corrente reforça a imagem do "dever ser" democrático (Assies, Calderón e Salman, 2002). Na mesma direção vai Ruggie (1998), que reconhece no mundo atual o "liberalismo incrustado" (embedded liberalism) e a democracia "tipo exportação", de moldes ocidentais, sendo propagada em escala global - as novas "democracias" iraquiana e afegã podem servir de ilustração para o argumento. David Held comenta que, no pós-Segunda Guerra, uma nova concepção do direito internacional passou a dar mais legitimidade às formas democráticas de governo (Held, 2004:129) ${ }^{13}$.

Os indícios levantados até aqui, a respeito da relação entre o processo de globalização e a (re)democratização latino-americana, são mistos ou ambivalentes. Stark tenta resumir, argüindo ser a globalização um amálgama de formas democratizantes e antidemocratizantes (apud Assies, Calderón e Salman, 2002). E é provável que, no caso latino-americano pelo menos, esteja com a razão. Se, por um lado, as forças internacionais, no pós-Guerra Fria, mostraram-se receptivas à proliferação da democracia eleitoral, do Estado democrático de direito e dos direitos civis, pareceu evidente também, por outro lado, o recuo do Estado em suas funções sociais e a mercantilização de várias de suas estruturas públicas (particularmente na América Latina). A lógica das relações econômicas internacionais, a um só tempo, avançou sobre alguns espaços públicos, e fez concessões estratégicas em outros tantos. Remodelaram-se as esferas do público e do privado, do interno e do internacional. 


\section{Dawisson Belém Lopes}

Por fim, como explicar a tibieza da noção de democracia no ideário dos cidadãos latino-americanos? Por que, afinal, há tamanha confusão sobre o conceito de democracia na América Latina? O que leva os cidadãos a abraçar a idéia de democracia e, ao mesmo tempo, rejeitar práticas e instituições democráticas ao seu redor?

Talvez seja esse o mais complicado feixe de questões que aqui tentarei atacar. Nohlen tem entendido que a tibieza do conceito de democracia na América Latina advém da falta de uma alternativa não-democrática no subcontinente. Explico: a grande diversidade de caracteres atribuídos ao conceito de democracia na América Latina acaba conduzindo à perda de identidade do próprio conceito (apud Zovatto, 2002:31). Dagnino (1994) e Doimo (1996) apontam no histórico dos movimentos sociais bons motivos para que o conceito de democracia na América Latina tenha tomado uma forma frouxa: a partir dos anos 1980, a noção de "cidadania" foi apropriada, com rapidez e voracidade, por um amplo espectro de atores sociais e políticos, na luta pela "democracia", contra os regimes autoritários. Com a transição democrática, cada distinto grupo tratou de dar uma acepção singular a noções como "democracia" e "cidadania". Outras noções afins, como a "participação" e a "capacitação", também ganharam novas conotações políticas - sendo ressignificadas no discurso governamental. Desse entrecruzamento de idéias, emergiu no debate político um conceito de democracia polissêmico; e, por isso, insegurança acerca de sua significação (Assies, Calderón e Salman, 2002:57-60) ${ }^{14}$.

Para O'Donnell (2004), a inconsistência da noção de democracia latino-americana tem outras raízes. O'Donnell prescreve um padrão mais ambicioso, em bases antropológicas: os cidadãos na América Latina tendem a reduzir a democracia à mera função de legitimar governos, sem a capacidade de conduzir - pela via representativa - a política. É o que se chamou, na literatura, de "democracia delegativa" - de acordo com Susan Stokes, um "subtipo democrático normativamente inferior" (Stokes, 1999:100).

Acerca do descompasso entre ideais democráticos e práticas/instituições democráticas em território latino-americano, DaMatta constatava o funcionamento de uma "dupla lógica". O professor registra um estranho padrão de convivência entre discursos incompatíveis sobre os direitos e a cidadania: ainda que os pronunciamentos oficiais e as leis do Estado garantam os plenos direitos a todo cidadão, nega-se à gran- 
de maioria da população o acesso a esses direitos no cotidiano. Segundo Roninger e Herzog, na construção do discurso "racionalizador", a ausência de tais direitos assume uma forma parcialmente verbal, entremeando-se a ideologias. Justificativas e autojustificativas se mesclam, buscando delimitar "raios de ação", no marco de um universo discursivo socialmente estruturado, com espaços para as ambigüidades (apud Assies, Calderón e Salman, 2002). A "dupla lógica", de DaMatta, e a construção do discurso "racionalizador" (uma espécie de jogo de linguagem), de Roninger e Herzog, ajudam a enxergar a difícil coexistência, na América Latina, de condutas e conceitos democráticos incoerentes entre si. Boa parte dos direitos (especialmente os políticos e sociais), na América Latina, serve mais como imagem do que propriamente como ferramenta (idem:63). O ideal democrático latino-americano raramente se faz conduta, raramente está esculpido nos procedimentos "democráticos". Antes: não passa de uma intenção moral, de um fetiche, de uma referência legitimadora do discurso político (cf. Roniger e Herzog, 2000).

\section{DEMOCRACIA, MERCADO E A SAÍDA SALOMÔNICA}

Reiterando o que se vem defendendo ao longo deste texto, há conexões bastante concretas entre as relações internacionais contemporâneas (especialmente, as de natureza econômica, comercial e financeira), as reformas estruturais do Estado latino-americano nos anos 1980 e 1990 (via de regra, orientadas pelos ditames do mercado internacional) e a democracia praticada na América Latina (formalista e pouco substanciosa, não constituindo obstáculo à orientação - em diversos aspectos, antidemocratizante - dos agentes do mercado).

O ordenamento internacional deveria ser respeitoso para com a diversidade dos países - entre eles e dentro de cada um deles. Mas o próprio PNUD alerta: "as práticas de poder reinantes nas relações internacionais não tendem a levar em conta essa necessidade" (2004a:197, tradução do autor). Esse impasse é vivenciado, dia após dia, pelos estados da América Latina. Paradoxalmente, a mesma globalização que erodiu a capacidade de ação dos governos, em particular a efetividade dos instrumentos de regulação econômica, demanda desses Estados a tarefa de manter a coesão social, com margens reduzidas para a manobra dos governantes. Mais ainda: como resultado do peso crescente das condicionalidades impostas por bancos internacionais de crédito e a grande mobilidade transfronteiriça do capital financeiro, vêem-se re- 
duzidos os espaços para a construção de modelos sociais e econômicos - esta, em tese, uma prerrogativa assegurada pelo regime democrático (PNUD, 2004a).

Para O'Donnell, responsável pelo marco conceitual do informe do PNUD (2004c), um Estado que se encontre submetido às condições vigentes na América Latina de hoje, ineficiente burocraticamente e "colonizado" economicamente, não pode cumprir a sua dimensão de legalidade. Oferece, quando muito, uma legalidade truncada. Esse Estado é incapaz de filtrar e moderar as desigualdades sociais; torna-se reprodutor ativo das desigualdades já existentes, facilitando-as inclusive, não resistindo às mais devastadoras conseqüências da globalização. O'Donnell dá o seu veredicto: "se existe um Estado ineficaz burocraticamente, truncado legalmente e colonizado economicamente, há então muito pouco Estado" (O'Donnell, 2004:50, tradução do autor). Ou, como pondera Alain Touraine, citado no mesmo documento do PNUD (2004c): “Na realidade, os Estados que não são verdadeiramente nacionais são aqueles que têm resistido com mais dificuldade à globalização" (:51, tradução do autor). Porém, o reconhecimento das constrições existentes na cena internacional não impõe aceitar qualquer fado com resignação. A reconquista (de parcela perdida) dos graus de liberdade dos estados nacionais é, hoje, em face das forças que emanam das relações econômicas internacionais, um desafio maior da política democrática - aquela que se propõe à construção e à expansão da cidadania, frisa o informe.

Sugeriu-se também, no curso desta exposição, a existência de uma lógica plutocrática (e tecnocrática) - cujo centro de dispersão está nos países ricos - a disputar espaços com a lógica democrática interna, estruturante da autoridade do Estado-nação latino-americano - ou do "Estado-para-a-nação", como quer O'Donnell (2004:51). Em verdade, no que respeita às relações entre mercado e democracia, costuma ocorrer um debate polarizado entre duas correntes: de um lado, os que crêem na convivência harmônica entre os dois elementos, mercado e democracia; de outro, os que acreditam impossível qualquer convivência. Aparenta equivocada a dicotomização do debate, nos termos anteriormente expostos, porque demasiado simplista, reducionista do fenômeno em voga. Nem tanto ao mar, nem tanto à terra - é o que se sugere, para uma abordagem mais equilibrada. Como reconhece o PNUD (2004c) há um "trade-off autêntico" entre democracia e mercado. Isso porque os mercados se balizam por razões financeiras, de curto prazo, 
e são excessivamente voláteis. Existe uma tensão inescapável entre o individualismo e a desigualdade que tendem a resultar do funcionamento dos mercados, e a igualdade que consagra a cidadania democrática e a conseguinte necessidade da existência de um espaço público para a tomada de decisão - evitando-se, assim, a privatização dos juízos, como querem certas forças do mercado. A tensão entre os princípios associados ao mercado - acumulação de renda, desigualdade econômica, elitismo - e à democracia - igualdade política, igualdade jurídica, capacidade de autodeterminação do "demos" - é dinâmica (idem, 2004a). Ao longo da história, vários foram os padrões de relacionamento que se firmaram entre as duas razões, a do mercado e a do Estado. Hanson (1999) alega, na perspectiva da teoria política, que a democracia foi constantemente apropriada como a ideologia de uma classe - em oposição, portanto, a outras classes, quais sejam, os aristocratas e os plutocratas. "A política era amplamente compreendida como um tipo de solução de compromisso entre as classes, o que levava a democracia e a plutocracia a viverem uma situação de paz tensa" (idem:85, tradução do autor). Essa "paz tensa" entre as forças plutocráticas e democráticas, retratada por Hanson, marcaria o princípio do século XX, período em que o filósofo espanhol Ortega y Gasset avistou uma "revolução das massas". Ocorria a "democratização consumista": "Conotações classistas da democracia foram gradualmente eliminadas em favor de uma concepção mais 'universal', baseada em um grupo social inclusivo de todos - os consumidores. À medida que as classes passam a ser entendidas em termos de [capacidade de] consumo, em vez da referência às relações de produção, a imagem de uma sociedade dividida em classes começou a desaparecer da retórica política dos Estados Unidos" (ibidem, tradução do autor).

A harmonia entre democracia e mercado era apenas aparente. A escassez de riqueza material, que sobreveio à crise internacional dos anos 1970, tornou inviável, para um Estado norte-americano endividado, satisfazer a demanda dos seus cidadãos por direitos e prerrogativas. Neoconservadores propuseram o recuo do Estado, alegadamente "sobrecarregado", como antídoto para o "destempero democrático" (Huntington) que se aliava às crescentes expectativas da população. Veio a "Revolução Econômica de Reagan". Przeworski concede:

"O dilema tradicional da Esquerda tem sido que até mesmo procedimentos democráticos [considerados] perfeitos podem manter uma plutocracia: o governo dos ricos sobre os pobres. A experiência históri- 
ca tem mostrado que a democracia é compatível com a pobreza e a desigualdade na esfera social e com a opressão nas fábricas, nas escolas, nas prisões e nas famílias. E o dilema tradicional da Direita tem sido o de que a democracia pode transformar-se no governo da maioria dos pobres sobre a minoria dos ricos. Os procedimentos democráticos podem ameaçar a propriedade, o poder político, na forma do sufrágio universal e do livre direito de associação, podem ser exercidos para limitar os direitos de propriedade" (Przeworski, 1994:56).

O equilíbrio precário entre a forças mercadológicas e democráticas, como o observado presentemente na América Latina, não constitui uma novidade histórica, conforme se pode facilmente constatar. São restritas as condições dentro das quais a democracia se torna um estado de equilíbrio entre as estratégias descentralizadoras de forças políticas autônomas (idem). Assim, contrariando uma crença grassante no senso comum, afirma-se que podem, sim, concorrer, no tempo e no espaço, as lógicas "de mercado" e "do Estado democrático". É justamente essa a característica do conceito historicamente forjado de democracia - uma forma de resistência à racionalidade plutocrática. Não cabe aqui negar a tensão natural existente entre mercado e Estado democrático; tampouco postular a incompatibilidade entre as duas instituições.

A lógica em que operam os mercados é, se não contida, danosa à política democrática. Não é à toa que a democracia pressupõe uma hierarquia entre a política e a economia; e, no limite, a autonomia da sociedade para ditar a forma como se organizará o seu mercado, pela via das eleições (PNUD, 2004a). Bem entendido esse aspecto, emite-se aqui um parecer: conjugar mercado e democracia, de forma percebida como justa pelos cidadãos nacionais, é outro grande desafio das sociedades contemporâneas. Mercados e estados democráticos podem e devem conviver. A democracia, em sua busca por limitar as exclusões que o mercado provoca, aumenta a legitimidade do sistema econômico; o mercado, ao limitar o poder do Estado sobre o cidadão, permite maior e melhor adesão à democracia $(\text { idem })^{15}$.

Não obstante, essa queda-de-braço na América Latina tem sido, até o presente, vencida pelas forças mercadológicas da economia internacional. A resultante vetorial é uma democracia latino-americana "deficitária"; e uma economia concentradora de renda. O que temos na América Latina é uma "democracia-conduta" (nos termos definidos 
pelo PNUD) descolada da "democracia-conceito" (ou seja, o ideal democrático $)^{16}$.

Constatou Zovatto a vinculação direta, por parte dos cidadãos, da democracia latino-americana aos valores da liberdade (35\%) e das eleições ( $27 \%$ dos entrevistados). Adiante, vimos como o conceito de democracia no subcontinente é apropriado de forma imprecisa, geralmente reportado ao contexto das lutas contra a ditadura e aos movimentos sociais. Guiou-se, por conseguinte, à polissemia e à indefinição do conceito. Ora, pergunto: não seria a democracia, para os cidadãos latino-americanos, um conceito "negativo", isto é, formulado em oposição à autocracia dos militares? Ao pugnarem pelos valores da liberdade e das eleições, não estariam os cidadãos latino-americanos tornando a denunciar, de forma reiterada no tempo, os abusos, maus-tratos e censuras de toda sorte, a que estiveram submetidos durante os anos de regime ditatorial? Não é a democracia na América Latina, antes de uma "cultura", um instinto de defesa? Estas, e outras tantas questões irrespondíveis, guardam possivelmente alguma relação explicativa com a tibieza da democracia praticada no subcontinente ${ }^{17}$.

No que tange à combinação de democracia e desenvolvimento socioeconômico (binário pretendido por $75 \%$ dos cidadãos latino-americanos, segundo PNUD (2004a; 2004b; 2004c)), sugerida por Seymour Lipset e canonizada em segmentos do pensamento ocidental, alguma desmitificação faz-se útil. Pois, a rigor empírico, o desenvolvimento socioeconômico de um país pode dar-se apartado de uma concepção mais substantiva de democracia (e.g., uma "revolução dos provimentos", com ênfase nas políticas do tipo supply-side, como a Revolução Industrial inglesa); pode, ainda, observar-se a realização de uma concepção de democracia mais "conteudista" sem o paralelo desenvolvimento socioeconômico (e. g., a "revolução das prerrogativas", na França de fins do século XVIII - para ficar com terminologias e exemplos de Dahrendorf). Przeworski é taxativo sobre o assunto: “o argumento de que a democracia só tem condições de perdurar se produzir um desempenho econômico satisfatório não é uma lei objetiva e inexorável" $(1994: 55)^{18}$.

Przeworski (idem) percebe que uma frase muita repetida nos novos países democráticos é que "a democracia deve produzir, senão...". As reticências, postadas ao final, acentuam o desfecho apocalíptico imaginado. Crê-se que a crise econômica possa levar os civis a se voltarem con- 


\section{Dawisson Belém Lopes}

tra a democracia, o que aumentaria as possibilidades de uma subversão vitoriosa, da volta aos regimes autoritários. O que escapa à percepção de jornalistas, acadêmicos e políticos (fatalistas) é que a sobrevivência de uma democracia não depende unicamente do desenvolvimento socioeconômico atingido, senão do concurso de condições e instituições. A Grande Depressão é ilustrativa: a despeito das dificuldades extremas que se abateram sobre os Estados Unidos da América, as suas estruturas institucionais mostraram-se resistentes à crise econômica. Segundo O'Donnell, "podem existir, em um Estado ineficaz, de legalidade truncada e baixo capital cívico, estruturas democráticas" (2004:50, tradução do autor). Trata-se de dois fenômenos distintos democracia e desenvolvimento -, que são presididos por lógicas, em certas situações, incongruentes (Przeworski, 1994; Przeworski et alii, 2000).

Em vista do desequilíbrio de forças entre mercado e Estado na contemporaneidade (evidenciado na seqüência de dados disponibilizados pelo PNUD (2004a; 2004b; 2004c) e discutidos ao longo do artigo), não parece acaciano reafirmar que os cidadãos latino-americanos, ao participarem de pleitos democráticos, limpos e livres, são a fonte de toda autoridade exercida sobre eles pelo Estado e pelo governo. Cidadãos não são - nem podem ser - meros portadores de direitos, em uma postura passiva. São a justificativa da pretensão de mando e autoridade que o Estado e o governo articulam, quando tomam decisões coletivamente vinculantes - eis a característica peculiar à democracia (O'Donnell, 2004:39). Afora a democracia, todos os outros tipos conhecidos de autoridade política derivam a sua legitimidade para governar de instâncias não-democráticas: direito divino, autoridade imemorial, conhecimentos privilegiados, posse de riquezas materiais. Ademocracia contemporânea dificilmente se exerce diretamente pelo povo, mas certamente provém do povo e, por isso, deveria ser para o povo. O que nos faz chegar à conclusão inescapável: quando forças não-democráticas passam a conduzir estados com regimes democráticos, vindo governar, não raramente, contra as camadas menos privilegiadas da população, é sinal consistente de que "algo de podre há no reino da América Latina"... 


\section{NOTAS}

1. “Os fisiocratas, ardentes defensores do mercado livre, eram também adeptos do despotismo esclarecido. Adam Smith, o pai da escola econômica inglesa, considerava os políticos animais 'astutos e insidiosos'; David Ricardo, seu maior sucessor entre os clássicos, era liberal, mas bem pouco democrata. Em tudo isso, não se sente nenhum afeto pela natureza da democracia representativa" (Merquior, 1982:133-134).

2. O índice global de reformas econômicas empregado pela CEPAL é de autoria de Samuel Morley, Roberto Machado e Stefano Pettinato (CEPAL, 1999). Envolve a aferição de cinco dimensões: abertura comercial, finanças domésticas, conta de capitais, impostos e privatizações; oscilando entre 0 (zero) e 1.

3. O índice global de reformas econômicas empregado pelo PNUD decompõe-se em cinco elementos: políticas de comércio internacional, políticas impositivas, políticas financeiras, privatizações e contas de capital; indo de 0 (zero) a 1.

4. Uma ressalva é providencial: a convergência institucional para um mesmo telos não significa, em nenhuma hipótese, instituições idênticas entre si. As diferenças contextuais definirão a formatação precisa, bem como o funcionamento das instituições. A rigor, a arquitetura institucional dos países pesquisados mostra-se diversificada. Ver Knight (2001); e North (1998).

5. É importante sublinhar que, para boa parte dos teóricos racionalistas da ciência política, a coerção irresistida e a emulação não constituem padrões de ação/escolha racional. Racional é toda ação/ escolha que, da perspectiva de um agente (individualismo metodológico), busca mobilizar determinados meios para atingir determinados fins, do modo mais eficiente possível (maximização).

6. Inferior apenas aos índices de ambivalência na Colômbia, El Salvador e Nicarágua (PNUD, 2004b).

7. Um contra-senso em termos, já que o virtual apoio ("condicionado" ao desenvolvimento econômico) que os latino-americanos esboçaram aos regimes autoritários implica a aceitação da "imposição da ordem pela via da força", se e quando necessário.

8. Possibilidade vislumbrada por Paramio (2002b), com as eleições brasileiras e bolivianas de 2002.

9. Para fim de registro momentâneo: o coeficiente de Gini no Uruguai é de 0,44; em Honduras, de 0,56; no Brasil, de 0,64. A média latino-americana é de 0,54.

10. Curiosamente, a percepção mais positiva de igualdade legal entre os países que temos acompanhado registrou-se em Honduras, onde 23,5\% dos entrevistados acreditam que um pobre pode, sim, fazer valer os seus direitos naquele país - contra 21,9\% no Uruguai e 20,1\% no Brasil. A noção de "grupo de referência" pode ajudar a encontrar explicações para o fenômeno (PNUD, 2004b).

11. Processo também denominado pelo autor de individuação (em alusão a Jean Piaget).

12. Cf. Weyland (2004) para uma defesa, por outro ângulo, do mesmo argumento.

13. É instigante perceber o apelo moral e ideológico das formas democráticas em um mundo globalizado: travam-se guerras e intervenções militares pela deposição de tiranos, cujos países são agrupados em um arbitrário "eixo do mal". Associam-se regimes não-democráticos, não raro, à megalomania bonapartista, ao culto ao terrorismo, à ganância nuclear ou à ineficiência econômica. Impõem-se embargos e sanções 


\section{Dawisson Belém Lopes}

às nações conduzidas por líderes autoritários. Ante o exposto, como não ser democrata em um mundo regido por "leis morais" liberal-democráticas? Não há de ser tarefa fácil - que o digam os cubanos, para ficarmos em um bom exemplo latino-americano.

14. Cf. Doimo (1996); e Dagnino (1994).

15. Sugere Rodrik (2002: 43-44): “a mera idéia de que os Estados e o mercado são complementares [...] possibilitou a prosperidade sem precedentes vivida por Estados Unidos, Europa Ocidental e parte do Extremo Oriente, na segunda metade do século $X X^{\prime \prime}$. Segundo o autor, a boa novidade do século XXI é que passamos a perceber, com maior nitidez, as virtudes das economias mistas.

16. "Democracia não é só conceito; é, principalmente, uma conduta" (Merquior, 1982:114, ênfases do autor).

17. Convém resgatar Raymond Williams, segundo quem "se estamos confusos sobre o sentido da democracia, então também estamos incertos se somos democráticos" (Hanson, 1999:85-86).

18. Cf. Przeworski et alii (2000), para uma rica abordagem da relação entre democracia e desenvolvimento econômico na segunda metade do século XX, em perspectiva histórica comparada.

\section{REFERÊNCIAS BIBLIOGRÁFICAS}

ASSIES, W., CALDERÓN, M. e SALMAN, T. (2002), “Ciudadanía, Cultura Política y Reforma del Estado en América Latina". América Latina Hoy, vol. 32, pp. 55-90.

BECK, U. (1995), “A Reinvenção da Política”, in U. Beck et alii (orgs.), Modernização Reflexiva. São Paulo, Editora da Unesp, pp. 11-72.

BOSCHI, R. (2004a), “Instituições Políticas, Reformas Estruturais e Cidadania: Dilemas da Democracia no Brasil". Disponível em http:observatorio.iuperj.br/artigos_resenhas, acessado em 28/7/2006.

. (2004b), “Desarrollo Democrático en América Latina: Su Condición, las Percepciones de sus Ciudadanos, Indicadores y Agenda", in PNUD, Informe La Democracia en América Latina - Anexo 2: El debate conceptual sobre la democracia en América Latina. Disponível em http:/ / www.undp.org, acessado em 28/7/2006.

CALDERÓN, F. (2002), Sociedad y Globalización. Cuaderno de Futuro no1. La Paz, PNUD.

CAMPBELL, J. L. e PEDERSEN, O. K. (eds.). (2001), The Rise of Neoliberalism and Institutional Analysis. Princeton, Princeton University Press.

CARDOSO, A. (2003), A Década Neoliberal e a Crise dos Sindicatos no Brasil. São Paulo, Boitempo.

CARDOSO, F. H. e FALETTO, E. (2004) [1967], Dependência e Desenvolvimento na América Latina - Ensaio de Interpretação Sociológica. Rio de Janeiro, Civilização Brasileira. 
COMISIÓN ECONÓMICA PARA AMÉRICA LATINA Y EL CARIBE - CEPAL. (1999), Indexes of Structural Reform in Latin America. Disponível em http:/ / www.eclac.org/ cgi-bin/getProd.asp?xml=/publicaciones $/$ xml/5/4275/P4275.xml\&xsl=/de / tpli/p9f.xsl\&base=/tpl/top-bottom.xslt, acessado em 28/7/2006.

CONAGHAN, C. e MALLOY, J. (1994), Unsettling Statecraft. Pittsburgh, University of Pittsburgh Press.

DAGNINO, E. (org.). (1994), Os Anos 90 - Política e Sociedade no Brasil. São Paulo, Brasiliense.

DOIMO, A. M. (1996), A Voz e a Vez do Popular: Movimentos Sociais e Participação Política no Brasil Pós-70. Rio de Janeiro, Relume Dumará.

FALK, R. (2000), Human Rights Horizons: the Pursuit of Justice in a Globalizing World. London, Routledge.

FUKUYAMA, F. (1992), The End of History and the Last Man. New York, The Free Press.

GILPIN, R. (2004), O Desafio do Capitalismo Global. Rio de Janeiro, Record.

GRAHAME, T. e HIRST, P. (1998), Globalização em Questão. Petrópolis, Vozes.

HAGGARD, S. (1990), Pathways from the Periphery. Ithaca, Cornell University Press.

HALL, P. e SOSKICE, D. (2001), Varieties of Capitalism: The Institutional Foundations of Comparative Advantage. Oxford, Oxford University Press.

HANSON, R. (1999), “Democracy”, in T. Ball, J. Farr e R. L. Hanson (eds.), Political Innovation and Conceptual Change. Cambridge, Cambridge University Press, pp. 68-89.

HELD, D. (2004), “El Estado de la Democracia en América Latina”. Informe La Democracia en América Latina - Anexo 2: El Debate Conceptual sobre la Democracia en América Latina. Disponível em http:/ /democracia.undp.org, acessado em 28/7/2006.

HENISZ, W., ZELNER, B. e GUILLÉN, M. (2004), “International Coercion, Emulation and Policy Diffusion: Market-Oriented Infrastructure Reforms, 1977-1999". Disponível em http://papers.ssrn.com/sol3/papers.cfm?abstract_id=557140, acessado em $28 / 7 / 2006$.

HOPENHAYN, M. (1998), “Cultura, Ciudadanía y Desarrollo en Tiempos de Globalización". Revista de Ciencias Sociales, no 5, pp. 30-50.

IKENBERRY, J. (1990), “The International Spread of Privatization Policies: Inducement, Learning and Policy 'Bandwagoning'”, in E. N. Suleiman e J. Waterbury (orgs.), The Political Economy of Public Sector Reform and Privatization. Boulder, Westview Press.

KAHLER, M. (1993), “Bargaining with the IMF: Two-Level Strategies and Developing Countries", in P. Evans, H. Jacobson e R. Putnam. Double-Edged Diplomacy: International Bargaining and Domestic Politics. Berkeley, University of California Press.

KNIGHT, J. (2001), “Explaining the Rise of Neoliberalism: Mechanics of Institutional Change", in J. L. Campbell e O. K. Pedersen (eds.), The Rise of Neoliberalism and Institutional Analysis. Princeton, Princeton University Press.

LIJPHART, A. (2003), Modelos de Democracia. Rio de Janeiro, Civilização Brasileira.

MERQUIOR, J. G. (1982), A Natureza do Processo. Rio de Janeiro, Nova Fronteira. 


\section{Dawisson Belém Lopes}

NAIM, M. (1993), “Latin America: Post-Adjustment Blues". Foreign Policy, vol. 92, pp. 133-150.

NORTH, D. (1998), “Economic Performance through Time”, in M. Brinton e V. Nee (eds.), The New Institutionalism in Sociology. Stanford, Stanford University Press.

O’DONNELL, G. (2004), “Notas sobre la Democracia en América Latina”. Informe La Democracia en América Latina - Anexo 2: El Debate Conceptual sobre la Democracia en América Latina. Disponível em http:/ / democracia.undp.org, acessado em 28/7/2006.

ORGANISATION FOR ECONOMIC CO-OPERATION AND DEVELOPMENT - OECD. (2000), OECD Economic Outlook 67. Disponível em http://www.oecd.org/ dataoecd /42/49/2087393. pdf, acessado em 28/7/2006

PARAMIO, L. (2002a), “La Crisis de la Política en América Latina”. América Latina Hoy, no 32 , pp. 15-28.

(2002b), "Reforma del Estado y Desconfianza Política". Revista del CLAD, no 24.

PEVEHOUSE, J. (2002), “Democracy from the Outside-In”. International Organization, vol. 56, no 3, pp. 515-549.

PROGRAMA DE LAS NACIONES UNIDAS PARA EL DESARROLLO - PNUD. (1999), Informe sobre el Desarrollo Humano en Uruguay. Disponível em http://www.undp. org.uy, acessado em 28/7/2006.

(2001), Informe sobre el Desarrollo Humano en Uruguay. Disponível em http:/ / www.undp.org.uy, acessado em 28/7/2006.

. (2002), Informe sobre el Desarrollo Humano en Honduras. Disponível em http:/ / www.undp.un.hn, acessado em 28/7/2006.

. (2004a), Informe La Democracia en América Latina - Hacia una Democracia de Ciudadanos y Ciudadanas. Disponível em http://www.democracia.undp.org, acessado em $28 / 7 / 2006$

(2004b), Informe La Democracia en América Latina - Anexo 1: Compéndio Estadístico. Disponível em http:/ / www.democracia.undp.org, acessado em 28/7/2006.

. (2004c), Informe La Democracia en América Latina - Anexo 2: El Debate Conceptual sobre la Democracia en América Latina. Disponível em http://www.democracia. undp.org, acessado em 28/7/2006.

PRZEWORSKI, A. (1994), Democracia e Mercado no Leste Europeu e na América Latina. Rio de Janeiro, Relume Dumará.

et alii. (2000), Democracy and Development: Political Institutions and Well-Being in the World, 1950-1990. Cambridge, Cambridge University Press.

REIS, F. W. (2000), Mercado e Utopia: Teoria Política e Sociedade Brasileira. São Paulo, Edusp.

RICUPERO, R. (2002), “Diversidade e Desenvolvimento", in G. Arbix et alii (orgs.), Brasil, México, África do Sul,Índia e China: Diálogo entre os Que Chegaram Depois. São Paulo, Edusp/Edunesp, pp. 25-42.

RODRIK, D. (2002). "Estratégias de Desenvolvimento para o Novo Século", in G. Arbix et alii (orgs.), Brasil, México, África do Sul, Índia e China: Diálogo entre os Que Chegaram Depois. São Paulo, Edusp/Edunesp, pp. 43-78. 
RONIGER, L. e HERZOG, T. (eds.). (2000), The Collective and the Public in Latin America. Cultural Identities and Political Order. Brighton, Sussex Academic Press.

RUGGIE, J. (1998), Constructing the World Polity: Essays on International Institutionalization. London/New York, Routledge.

SACHS, J. (ed.). (1989). Developing Country Debt and Economic Performance. Chicago, Chicago University Press, vol. 1.

STOKES, S. (1999), “What Do Policy Switches Tell Us About Democracy?”, in A. Przeworski et alii (eds.), Democracy, Accountability and Representation. Cambridge, Cambridge University Press.

VELTMEYER, H., PETRAS, J. e VIEUX, S. (1997), Neoliberalism and Class Conflict in Latin America: A Comparative Perspective on the Political Economy of Structural Adjustment. New York, Palgrave Macmillan.

WEYLAND, K. (1998), The Politics of Neoliberal Reform in Latin American Democracies: Argentina, Brazil, Peru, and Venezuela. Trabalho apresentado no painel Democracy and the New Market Model in Latin Americana, na XXI Conferência Internacional da Latin American Studies Association - LASA. Chicago, 24-26 de setembro.

(2002), The Politics of Market Reform in Fragile Democracies. Princeton, Princeton University Press.

. (2004), “Neoliberalism and Democracy in Latin American: A Mixed Record". Latin American Politics and Society, vol. 46, no 1, pp. 135-157.

ZOVATTO, D. (2002), “Valores, Percepciones y Actitudes hacia la Democracia. Una Visión Comparada Latinoamericana: 1996-2002". América Latina Hoy, no32, pp. 29-53. 


\begin{abstract}
International Economic Relations. Institutional Isomorphism and

Democracy in Latin America. Explaining the (Unexpected?) Convergences between Uruguay, Brazil and Honduras
\end{abstract}

Along this article, we sought to apprehend the logic underlying the triangular relation between international economic powers, structural reforms of the State, and democracy in Latin America. The study is based on the findings expressed in the Report on "A Democracia na América Latina: Rumo a uma Democracia de Cidadãs e Cidadãos" ["Democracy in Latin America: towards a Democracy of Female and Male Citizens"] (PNUD, 2004). The data subject to scrutiny refer to three States - Uruguay, Brazil and Honduras. Two hypotheses have been tested: (1) structural reforms of the State in Latin America have been conditioned by the dynamics of the international economy; and (2) the democracy that is possible in Latin America is a formalist democracy, and it does not inhibit the rational choice of market oriented economic agents. The conclusions of this work are discussed in the light of political theories and international relations.

Key words: democracy; institutions; Latin America

\author{
RÉSUMÉ \\ Relations Économiques Internationales, Isomorphisme Institutionnel et \\ Démocratie en Amérique Latine. Explication des Convergences \\ (Inattendues?) entre l'Uruguay, le Brésil et Honduras
}

Dans cet article, on cherche à saisir la logique sous-jacente à la relation triangulaire entre les forces économiques internationales, les réformes structurelles de l'État et la démocratie en Amérique Latine, d'après les résultats diffusés dans le document "La démocratie en Amérique Latine: vers une démocratie de citoyennes et citoyens" (PNUD, 2004). Les données concernant trois pays - Uruguay, Brésil et Honduras - sont analysées attentivement. On cherche à vérifier deux hypothèses: 1) en Amérique Latine, les réformes structurelles de l'État ont été soumises à la dynamique de l'économie internationale; et 2) la démocratie possible en Amérique Latine est formaliste puisqu'elle n'empêche pas le choix rationnel des agents économiques, guidés par le marché. Les résultats de l'analyse sont discutés à la lumière des théories politiques et des relations internationales.

Mots-clé: démocratie; institutions; Amérique Latine 